Review

\title{
What Do We Know about Co-Working Spaces? Trends and Challenges Ahead
}

\author{
Jasmina Berbegal-Mirabent
}

check for updates

Citation: Berbegal-Mirabent, J. What Do We Know about Co-Working Spaces? Trends and Challenges Ahead. Sustainability 2021, 13, 1416. https://doi.org/10.3390/su13031416

Academic Editors: Martí Casadesús, Paulo Sampaio and Frederic Marimon Received: 30 December 2020

Accepted: 26 January 2021

Published: 29 January 2021

Publisher's Note: MDPI stays neutral with regard to jurisdictional claims in published maps and institutional affiliations.

Copyright: (C) 2021 by the author. Licensee MDPI, Basel, Switzerland. This article is an open access article distributed under the terms and conditions of the Creative Commons Attribution (CC BY) license (https:/ / creativecommons.org/licenses/by/ $4.0 /)$.
Department of Economics and Business Organization, Univeristat Internacional de Catalunya, 08017 Barcelona, Spain; jberbegal@uic.es

\begin{abstract}
Co-working spaces (CWSs) have emerged as a distinctive phenomenon in the sharing economy. They are collaborative environments that feed innovation and creativity under the slogan "working alone together". While policy makers and scholars were optimistic about their role in promoting entrepreneurial endeavours and fostering growth, the spread of the COVID-19 across the world has drastically changed the way we work, communicate, and navigate daily life. This study offers a comprehensive review of the existing literature on CWSs. To do so, a bibliometric analysis is proposed, combining the use of traditional bibliometric tools with science mapping techniques. A total of 118 documents are reviewed and the results are presented at two different levels: (1) descriptive analysis of the status of the research on a CWS and (2) its conceptual structure (topics and trends). The study concludes with some directions for future research. Specifically, based on the recurrent topics discussed up to date in the literature, it is possible to identify four key areas-i.e., geographical location, physical space, business models and inclusive communities-that are promising for research and that may bring useful insights for defining co-working's place in a post-pandemic society.
\end{abstract}

Keywords: co-working; trends; literature review; bibliometrics; sharing economy; pandemic

\section{Introduction}

During the past decade, the pressure for adopting green practices has mounted, not only at the corporate but also at the individual level. Businesses and people are seeking more sustainable ways to live and work. Within this context, we have witnessed the rise of the sharing economy across a wide range of industries, including the proliferation of a number of shared office spaces in and around cities [1]. These spaces-commonly referred as co-working spaces (CWSs) - are collaborative environments which are found to feed innovation and creativity. As signalled by Spinuzzi [2] the new trend is about "working alone together". Innovation rarely occurs in isolation [3]; on the contrary, meeting other people increases the chances of knowledge exchange, [4] and consequently, the likelihood of generating new ideas and exploring novel business opportunities [5,6]. Equally important is the access to resources, services and assistance in support of innovation $[7,8]$. CWSs do offer all these services.

While this trend was almost unheard in the earlies 2000s, the Global Coworking Survey elaborated by DeskMag (https:/ / www.deskmag.com/en/) indicated that by the end of 2019, 2.2 million people were working in 22,000 co-working spaces around the world. One of the main drivers for this growth has been the rise of a new generation of workersmainly entrepreneurs and freelancers-which are disrupting the traditional way of how and where to work, by breaking down corporate hierarchies, dismantling mentalities, redefining social norms and increasingly experimenting with new work practices and unconventional offices [9]. The pace of globalization and the new advances in digital and mobile technologies have further enabled professionals to work from almost anywhere [10]. Likewise, the adoption of agile and lean practices has altered fundamental aspects of the 
work culture and requires new approaches that are better suited to the current needs. Coffee houses, libraries and hotels offer the attractiveness of being intermediate spaces between home and work, away from distractions. At the same time, they provide a social and inspiring atmosphere. However, a common drawback of these spaces is that their primarily purpose is not to provide a collaborative environment to work [11], but instead, a place where to drink a coffee, read a book or stay one night. CWSs do fulfil the above requirements.

Last but not least, CWS are found to be spatially concentrated within the inner precincts of urban environments [12], the preferable place of millennials. This is remarkable if we consider that most co-workers could probably equally work from anywhere with internet connection. Millennials are in search of places where they can work and, at the same time, enjoy a thrilling atmosphere [13]. City centres are eager to attract this new generation of workers, yet the increased cost of renting is a great impediment for many of them to set their offices there. CWSs are thus appealing because they represent a low-rent alternative in the middle of the compactness of the metropolis.

Both policy makers and scholars are optimistic about the role of CWSs in feeding innovation and creativity, promoting entrepreneurial endeavours [1,12] and urban revitalisation [14,15]. Likewise, CWSs have a huge potential to support environmental sustainability and may become a sustainable future [16], not only they are less harming to the environment but they also create a sense of community, family and friendship, a characteristic that drives people to commit to a change [17]. Data from GCUC further revealed a promising future for the $\mathrm{CW}$ industry, projecting circa 5.1 million people hosted in more than 30,432 co-working spaces by 2022. Then, the COVID-19 emerged unexpectedly and abruptly in just the span of a few weeks, altering almost every facet of our lives, so also that of the CWS.

The pandemic and subsequent lockdown has left CWSs with large amounts of empty spaces and hundreds of furloughed employees. The average occupancy of co-working operators has significantly dropped, and those spaces that survived have entered a price war, with offers of shortages and discounts of up to $50 \%$. Notwithstanding, there is also some hope left. Although the crisis has had a great impact on all operators-both large and small —and unfortunately, many of them have disappeared, the industry is moving forward. By recognising the accelerated demand for flexibility, both in the current situation and post-pandemic return to the office, new opportunities are being created, and CWSs can become an attractive solution in such a period of uncertainty. It is still too early to know how the co-working of the future will look like, yet, we have started witnessing a variety of practices that are worth to be surveyed.

Rooted in this context, it is believed to be the perfect timing for reviewing how CWSs have evolved since their inception and the future that might hold for this industry. With this purpose in mind, this study contributes to the current conversations on CWSs in two main ways. First, to the best of the author's knowledge there is no structured literature available focusing on CWSs. Drawing a picture of a field of knowledge is highly desirable as it reveals who is interested in a given topic (authors, institutions, countries), what are scholars talking about (themes and trends) and how the work of an author influences the scientific community. Accordingly, building upon the existing works a comprehensive overview of the past and present research on this field is provided. To address this goal a bibliometric analysis is conducted which, using science mapping techniques, identifies the most relevant authors, journals, institutions and countries. In addition, it maps out the conceptual structure of the field-themes and topics discussed over time. One hundred eighteen documents extracted from the Web of Science (WoS) database are analyzed. Second, there is no doubt that the coronavirus outbreak and its subsequent restrictions have permanently altered many elements of how we work. Aiming at providing some insights into what the future of CWSs may look like, this study also discusses the current challenges the co-working industry is facing as a result of the COVID-19, and based on them potential avenues for future research are put forward. 
The remaining of the article is structured as follows. Section 2 describes the methodological approach. After that, Section 3 presents the state-of-the-art of the existing research on CWSs, and Section 4 focuses on the conceptual structures and intellectual roots. Next, Section 5 puts forward ideas for future research in the domain of CWSs in the light of a post-pandemic situation. The paper ends with the concluding remarks in Section 6.

\section{Research Methods}

\subsection{Data Collection}

The research method starts with the selection of the dataset. For the purpose of this study Web of Science (WoS) was chosen. This database is one of the most extensive indexing platforms worldwide [18] and integrates research from different academic disciplines and multiple sources, on the basis of impact evaluations fulfilling the highest quality standards [19].

In order to restrict the number of documents and concentrate on the most illustrative pieces, only "journal articles" and "reviews" written in English were selected. The selection of meaningful keywords was the next step. To make sure the query only returned relevant records investigating CWSs, the chosen keywords needed to be broad enough to include studies that address this topic from its multiple perspectives-i.e., tenants, co-workers, founders, public administration - but also the search query should contain specific words that allowed narrowing down the search and exclude documents in which the term coworking was used for a different purpose than that of referring to two or more people working in the same place-e.g., in a shared office—but not for the same company. Having the above considerations in mind, the search query was formulated as follows: (co-working or coworking) and (sharing or collaborative or space*). The algorithm looked for the inclusion of these terms in the title, abstract and/or keywords. No restrictions were posed in terms of the time period. The search was conducted in December 2020, resulting in 216 documents.

The metadata of the retrieved documents by WoS in Bib TeX format was exported into an Excel sheet. At this stage the abstract of each document was reviewed and, in case of doubt about the fit, the full document was downloaded and revised. Although the strict filters applied, 97 articles were discarded. Main domains in which these documents felt in were:

- $\quad$ Design of learning spaces (schools and higher education)

- Literature reviews on circular and sharing economy

- Smart cities, entrepreneurship, innovation hubs, incubators and creative labs

- Human-robot interaction

- Information systems

The final sample contains 118 documents, from which 115 are journal articles and only 3 are reviews. The first publication is dated in 2012 and the newest one is from 2020. Figure 1 graphically illustrates the inclusion/exclusion criteria and the resulting number of documents at each stage. 


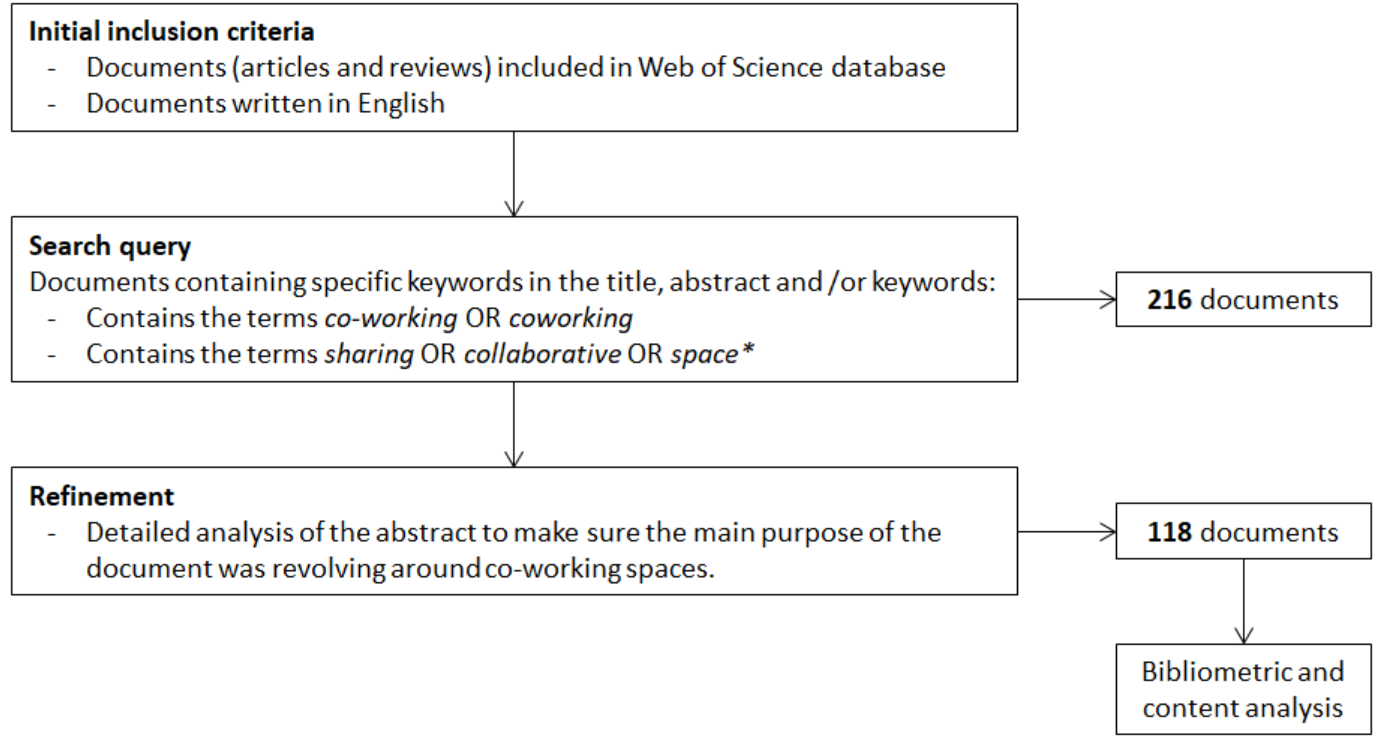

Figure 1. Data collection flow diagram with the summary of the applied steps.

\subsection{Data Treatment}

In the recent years, the number of bibliometric studies has significantly grown. Such studies are relevant for a discipline as they provide a comprehensive picture of the existing conversations in a given field. This is particularly useful in an era with an overwhelming volume of new works being published every day. In this context, bibliometric studies are thus very useful, as they provide a structured analysis of a large body of information and allow researchers to identify the most relevant contributions, prolific authors and institutions, as well as to infer trends and identify shifts in the boundaries of disciplines. Managing such amount of information manually is almost impossible. Thanks to the rise of computational advancements, new tools have been developed aimed at supporting science mapping analysis. Some of the most prominent tools for bibliometric analysis that have been developed include bibliometrix [20], CitNetExplorer [21], SciMAT [22] and VOSviewer [23]. For the purpose of this study bibliometrix - an open-source tool developed in $\mathrm{R}$-and more specifically, biblioshiny — the shiny app that provides a web-interface for bibliometrix-was selected.

As pointed above, bibliometric studies are valuable, yet, while documenting what is out there is interesting, the analysis needs to dive into the substance of the works in order to advance the understanding of the phenomenon under investigation. Therefore, when designing this study special attention was put on the works published by the developers of Bibliometrix $[24,25]$ as well as on other relevant works that employ this software package and go beyond descriptive findings to create interpretations (e.g., [26-28]).

Before importing the file with all the metadata into the biblioshiny app, it was necessary to manually check for accuracies in the spelling of the keywords. The analyses reported in this study are based on KeyWords Plus. These words-or short sentences-are terms that typically appear in the titles of the references cited in the paper but are not included elsewhere in the document. Using machine learning techniques Clarivate Analytics (the company that develops WoS) identifies these words from a standardized glossary created by a panel of experts. Although authors typically include their own keywords in a document, the use of KeyWords Plus is preferable in bibliometric analysis as the terms are not biased and are more descriptive [29]. When revising the KeyWord Plus in the metadata of our dataset it was noted that some of the terms were not standardized, including singular and plural versions of the same concept (i.e., start-up and start-ups), were not consistent in the use of hyphen (e.g., co-working and coworking) or used different English spelling (e.g., organization and organisation). Therefore, all keywords were manually checked to make sure the spelling was homogenized. 
As Table 1 reveals, the dataset contains 118 documents (all articles, although 6 of them are also classified as "book chapters" or "proceedings paper") published between 2012 and 2020, representing the work of 226 authors. 31 of these articles are single-authored works; nevertheless, the dominant trend is to have 2.36 co-authors per document. On average, each document has received 9.97 citations, with an average rate of 3.06 citations per year. The detailed list of the papers included in this review can be found in Appendix A.

Table 1. Main descriptives of the selected documents.

\begin{tabular}{|c|c|c|}
\hline Agent & Description & Results \\
\hline \multirow{7}{*}{ Main information about data } & Timespan & 2012-2020 \\
\hline & Sources (journals, books, etc.) & 84 \\
\hline & Documents & 118 \\
\hline & Average years from publication & 1.80 \\
\hline & Average citations per documents & 9.97 \\
\hline & Average citations per year per document & 3.06 \\
\hline & References & 5469 \\
\hline \multirow{5}{*}{ Document types } & article & 95 \\
\hline & article; book chapter & 2 \\
\hline & article; early access & 14 \\
\hline & article; proceedings paper & 4 \\
\hline & review & 3 \\
\hline \multirow{2}{*}{ Document contents } & Keywords Plus (ID) & 279 \\
\hline & Author's Keywords (DE) & 501 \\
\hline \multirow{4}{*}{ Authors } & Authors & 226 \\
\hline & Author appearances & 279 \\
\hline & Authors of single-authored documents & 29 \\
\hline & Authors of multi-authored documents & 197 \\
\hline \multirow{5}{*}{ Authors collaboration } & Single-authored documents & 31 \\
\hline & Documents per author & 0.52 \\
\hline & Authors per document & 1.92 \\
\hline & Co-authors per documents & 2.36 \\
\hline & Collaboration index & 2.26 \\
\hline
\end{tabular}

\subsection{Analysis}

The documents contained in the dataset have been analyzed in two different ways. First, a descriptive analysis is provided, showing a general overview of the existing literature on CWSs. The results are reported in Section 3 and include the analysis of the distribution of documents over time, the most cited documents, the authors that are at the forefront in this specific field, the most prolific countries, as well as the most recurrent sources (e.g., journals, book series, etc.) were researchers tend to publish their works.

Second, the study takes a step forward and dives deeper into the topics discussed by researchers and scrutinizes the potential temporary trends that can be observed (Section 4). Using co-word analysis and combining traditional performance analysis with science mapping techniques, the interconnections between the key terms used in the documents are explored to construct the conceptual structure of the existing research on CWSs. At this stage, three instruments are used: the word map, the co-occurrence network and the thematic map. Based on KeyWords Plus, the word map uses factorial analysis-in this study, multiple correspondence analysis (MCA) - as a data reduction technique to assists in the identification of clusters of words that might refer to different subfields. The second tool, the co-occurrence network graphically illustrates in the form of a network the keywords extracted from the documents and shows the relationships among them. Each keyword is shown as a node and the edge connecting two nodes is proportional to the number of times the two keywords are included in the same keyword list [30]. The closer the keywords are, the larger the proportion of articles that treat them together. Finally, a thematic map is created, which plots in a bidimensional matrix the clusters identified in the 
co-occurrence network. Two measures are considered [31]: centrality (in the $x$-axis), which can be interpreted as a measure of the importance of a theme in the development of the field (i.e., interaction of a given cluster with the other clusters); and density (in the $y$-axis), which can be read as the internal strength or cohesion of a cluster network. In this graph, the size of a cluster is proportional to the words contained, and the label reflects the most frequently used keywords in it. The graphical representation results into four quadrants:

- Motor themes (upper-right quadrant): clusters of keywords well developed and important for the organizing of the research field.

- Developed and isolated themes (upper-left quadrant): clusters of keywords that are of limited significance and are not much connected with other themes.

- Emerging or declining themes (lower-right): to proper identify whether the clusters of keywords are emerging or declining a longitudinal analysis is necessary. Therefore, the period under analysis is split into two time slices to investigate the trajectory of these clusters. The year 2017 was chosen as a cutting point, given the change observed in the slope at this point of time (as it will be later commented in Figure 2). Therefore, two periods are examined (2012-2017 and 2018-2020).

- $\quad$ Basic and transversal themes (lower-left quadrant): clusters of keywords that refer to general topics and are transversal to different research areas within the field.

Finally, taking into account the topics covered up to date and after a careful examination of the emerging initiatives and approaches that CWSs have started adopting as a result of the COVID-19, Section 5 elaborates on potential directions for future research by looking at four key characteristics: the geographical location, the physical space, the business model and the creation of inclusive communities.

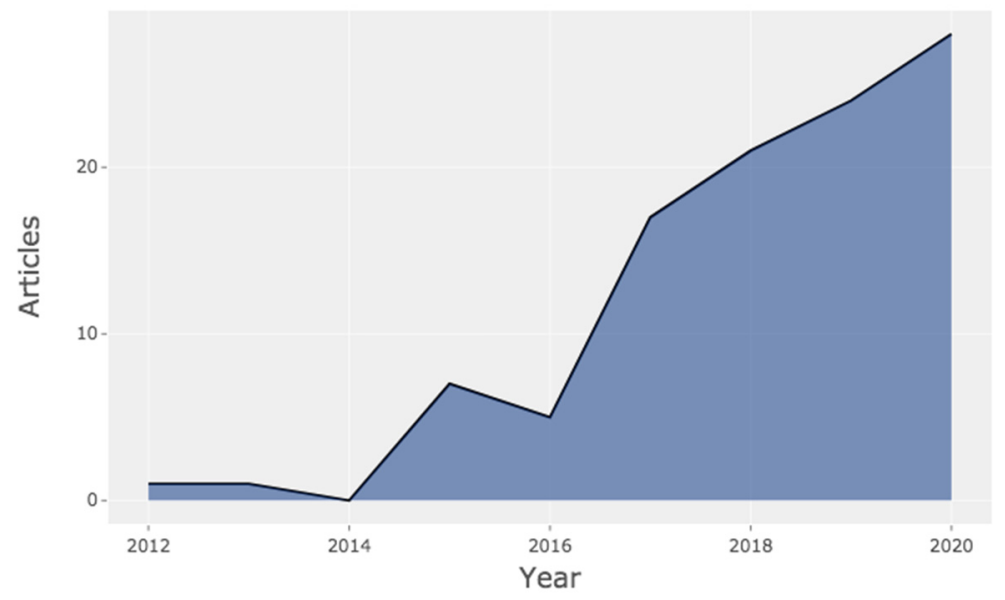

Figure 2. Annual distribution of the 118 documents that have been revised. Source: own compilation based on the records extracted from the Web of Science.

\section{Status of Research on Co-Working Spaces}

Although the academic community seems to not have paid much attention to the phenomenon of CWSs until recently - the first academic document in the dataset was published in 2012 - one of the first initiatives of a shared space with free public access to the internet where to work and meet was C-base, a hackerspace that dates back in 1995 in Berlin. After that, similar spaces started to pup-up with the aim to support collaborative work with the pioneer sites of 116 West House and 42 West 24 in the city of New York. It is remarkable that despite these first shared offices placed more emphasis on the flexible conditions rather than on the community aspect, this later characteristic has become the blueprint for the co-working industry. However, it is not until 2005 with Brad Neuberg-a software engineer-when the co-working phenomenon officially started in a collective space in San Francisco, located in the walls of Spiral Muse, a feminist collective [32]. About a year after, he relocated to the Hat Factory, the world's first full-time CWS. Given the overwhelming demand for this concept, many other spaces adopting a similar approach 
rapidly appeared all over the globe, cementing its power as a global trend. In 2009, the Global Coworking Unconference Conference was established and has become a relevant institution in the co-working industry. Since its official start in 2012, they have hosted over 30 conferences across the globe (https://gcuc.co/about/).

It is precisely at this point-in 2012-when the interest for CWSs also captured the interest of researchers. Figure 2 shows the distribution over time of the 118 documents that have been analyzed. Clay Spinuzzi [2] is the author of the first article (Working alone together: Coworking as emergent collaborative activity). In his study he reports a 2-year investigation of nine CWSs in Austin in order to find an answer to three questions: What is co-working? Who co-works? Why do people co-work? Not surprisingly this study has become one of the seminal works in the field, accumulating a high number of citations (see Tables 2 and 3).

As shown in Figure 2, until 2017 the number of publications investigating CWSs was limited; however, as the number of CWSs started growing-so as the number of independent associations supporting their endeavors-researchers also began considering this phenomenon more closely. Just as we are about to close the year, 28 articles on CWSs have been published in 2020, and there are 14 additional ones pending of being assigned an issue which have collectively received nine citations.

Table 2. Documents by year.

\begin{tabular}{|c|c|c|c|c|c|}
\hline Year & $\begin{array}{l}\text { Number of } \\
\text { Articles }\end{array}$ & $\begin{array}{c}\text { Total Number of } \\
\text { Citations }\end{array}$ & $\begin{array}{l}\text { Average Number of } \\
\text { Citations per Article }\end{array}$ & $\begin{array}{c}\text { Average Number of } \\
\text { Citations per Year }\end{array}$ & $\begin{array}{l}\text { Citable } \\
\text { Years }\end{array}$ \\
\hline 2012 & 1 & 189 & 189.00 & 23.63 & 8 \\
\hline 2013 & 1 & 52 & 52.00 & 7.43 & 7 \\
\hline 2014 & 0 & 0 & 0.00 & 0.00 & 0 \\
\hline 2015 & 7 & 185 & 26.43 & 5.29 & 5 \\
\hline 2016 & 5 & 73 & 14.60 & 3.65 & 4 \\
\hline 2017 & 17 & 294 & 17.29 & 5.76 & 3 \\
\hline 2018 & 21 & 208 & 9.90 & 4.95 & 2 \\
\hline 2019 & 24 & 129 & 5.38 & 5.38 & 1 \\
\hline 2020 & 28 & 38 & 1.36 & NA & 0 \\
\hline Not assigned & 14 & 9 & 0.64 & NA & $0-1$ \\
\hline
\end{tabular}

Table 3 shows the articles from the dataset that have received the highest number of citations (the cut-off point was set at 15). Two columns capture the number of citations. The first one (local citations) accounts for the number of citations received from other documents in the analyzed collection, while the later (global citations) measures the total number of citations from any paper indexed in the WoS. The number in brackets in the fifth column shows the percentage of local citations relative to global ones, revealing the relevance of each of the articles within its specific domain. The high scores in almost all documents indicate that these articles are, to some extent, specific in their topic, therefore, validating the inclusion/exclusion criteria followed in the selection process. There are only two articles that more than half of their citations come from different areas. These are the works of Bouncken and Reuschl [1], with a high percentage of citations coming from the literature on entrepreneurship and the study by Bilandzic and Foth [33] which examines the role of libraries as spaces that can stimulate co-working practices.

The biblioshiny app is a nice tool that allows to visually depict the intellectual linkages between documents in a historical order [20]. To do this the $\mathrm{R}$ package relies on citation analysis. This information is depicted in Figure 3. From this image it is possible to infer how the work of an author-from those in the dataset-has influenced the academic community working in this area. Based on the directions of the arrows it can be concluded that the first studies have connections with the most recent papers signaling that they are not declining in popularity, rather they are still relevant works. 
Table 3. Most cited documents. Local and global citations refer to the number of citations a document has received among those included in the dataset and indexed in the WoS, respectively. The numbers in brackets next to these numbers report the number self-citations. The percentage in the fifth column shows the proportion of local citations relative to global ones.

\begin{tabular}{|c|c|c|c|c|c|}
\hline Authors & Year & Title & Source & $\begin{array}{c}\text { Local } \\
\text { Citations }\end{array}$ & $\begin{array}{l}\text { Global } \\
\text { Citations }\end{array}$ \\
\hline Spinuzzi, C & 2012 & $\begin{array}{l}\text { Working alone together: Coworking } \\
\text { as emergent collaborative activity }\end{array}$ & $\begin{array}{l}\text { Journal of Business and } \\
\text { Technical } \\
\text { Communication }\end{array}$ & $\begin{array}{c}79(1) \\
(42.33 \%)\end{array}$ & $189(6)$ \\
\hline Parrino, L & 2015 & $\begin{array}{l}\text { Coworking: Assessing the role of } \\
\text { proximity in knowledge }\end{array}$ & $\begin{array}{l}\text { Knowledge } \\
\text { Management Research \& } \\
\text { Practice }\end{array}$ & $\begin{array}{c}35(0) \\
(71.43 \%)\end{array}$ & $49(0)$ \\
\hline $\begin{array}{l}\text { Garrett, LE; Spreitzer, } \\
\text { GM; Bacevice, PA }\end{array}$ & 2017 & $\begin{array}{l}\text { Co-constructing a sense of } \\
\text { community at work: The emergence } \\
\text { of community in coworking spaces }\end{array}$ & Organization Studies & $\begin{array}{c}31(0) \\
(60.38 \%)\end{array}$ & $53(0)$ \\
\hline $\begin{array}{l}\text { Bouncken, RB; } \\
\text { Reuschl, AJ }\end{array}$ & 2018 & $\begin{array}{l}\text { Coworking-spaces: How a } \\
\text { phenomenon of the sharing economy } \\
\text { builds a novel trend for the } \\
\text { workplace and for entrepreneurship }\end{array}$ & $\begin{array}{l}\text { Review of Managerial } \\
\text { Science }\end{array}$ & $\begin{array}{c}31(4) \\
(46.27 \%)\end{array}$ & $67(7)$ \\
\hline Capdevila, I & 2015 & $\begin{array}{l}\text { Co-working spaces and the localized } \\
\text { dynamics of innovation in Barcelona }\end{array}$ & $\begin{array}{l}\text { International Journal of } \\
\text { Innovation Management }\end{array}$ & $\begin{array}{c}26(0) \\
(61.9 \%) \\
\end{array}$ & $42(0)$ \\
\hline Fuzi, A & 2015 & $\begin{array}{l}\text { Co-working spaces for promoting } \\
\text { entrepreneurship in sparse regions: } \\
\text { The case of South Wales }\end{array}$ & $\begin{array}{l}\text { Regional Studies, } \\
\text { Regional Science }\end{array}$ & $\begin{array}{l}26(0) \\
(65 \%)\end{array}$ & $40(0)$ \\
\hline Rus, A; Orel, M & 2015 & Coworking: A community of work & Teorija in Praksa & $\begin{array}{c}23(6) \\
(82.14 \%)\end{array}$ & $28(6)$ \\
\hline Brown, J & 2017 & $\begin{array}{l}\text { Curating the third place? Coworking } \\
\text { and the mediation of creativity }\end{array}$ & Geoforum & $\begin{array}{c}22(0) \\
(62.86 \%)\end{array}$ & $35(0)$ \\
\hline Bilandzic, M; Foth, M & 2013 & $\begin{array}{l}\text { Libraries as coworking spaces. } \\
\text { Understanding user motivations and } \\
\text { perceived barriers to social learning }\end{array}$ & Library Hi Tech & $\begin{array}{c}21(1) \\
(40.38 \%)\end{array}$ & $52(6)$ \\
\hline $\begin{array}{l}\text { Spinuzzi, C; Bodrozic, } \\
\text { Z; Scaratti, G; Ivaldi, S }\end{array}$ & 2019 & $\begin{array}{l}\text { Coworking is about community: But } \\
\text { what is community in coworking? }\end{array}$ & $\begin{array}{l}\text { Journal of Business and } \\
\text { Technical } \\
\text { Communication }\end{array}$ & $\begin{array}{c}20(2) \\
(83.33 \%)\end{array}$ & $24(4)$ \\
\hline $\begin{array}{l}\text { Gerdenitsch, C; Scheel, } \\
\text { TE; Andorfer, J; } \\
\text { Korunka, C }\end{array}$ & 2016 & $\begin{array}{l}\text { Coworking spaces: A source of social } \\
\text { support for independent } \\
\text { professionals }\end{array}$ & Frontiers in Psychology & $\begin{array}{l}19(0) \\
(76 \%)\end{array}$ & $25(1)$ \\
\hline Kojo, I; Nenonen, S & 2016 & $\begin{array}{l}\text { Typologies for co-working spaces in } \\
\text { Finland: What and how? }\end{array}$ & Facilities & $\begin{array}{c}16(1) \\
(66.67 \%)\end{array}$ & $24(2)$ \\
\hline
\end{tabular}

The work of Spinuzzi [2] on the left side of the graph constitutes the starting point and has served as a base for the development of new advances. The work of Bilandzic and Foth is also relevant [33] as it has inspired a number of authors to examine the role of other shared spaces that combine a comfortable atmosphere for working with a social interface (e.g., libraries, cafés, learning centers, etc.). The study by Schopfel et al. [34]which appears next in the graph-is an excellent example of this, and it explores how the idea behind co-workings is a promising concept for academic libraries.

Other key works that have influenced and are still influencing the literature on CWSs are the studies elaborated by Fuzi [35], Capdevila [36] and Parrino [37]. While the first two look at co-workings as spaces that provide support and enable entrepreneurs to start and grow their businesses (either in the inner cities or in areas with weak entrepreneurial tradition), the latest focuses on the elements at the organizational level that stimulate collaboration among co-workers and ultimately, promote knowledge exchange. 


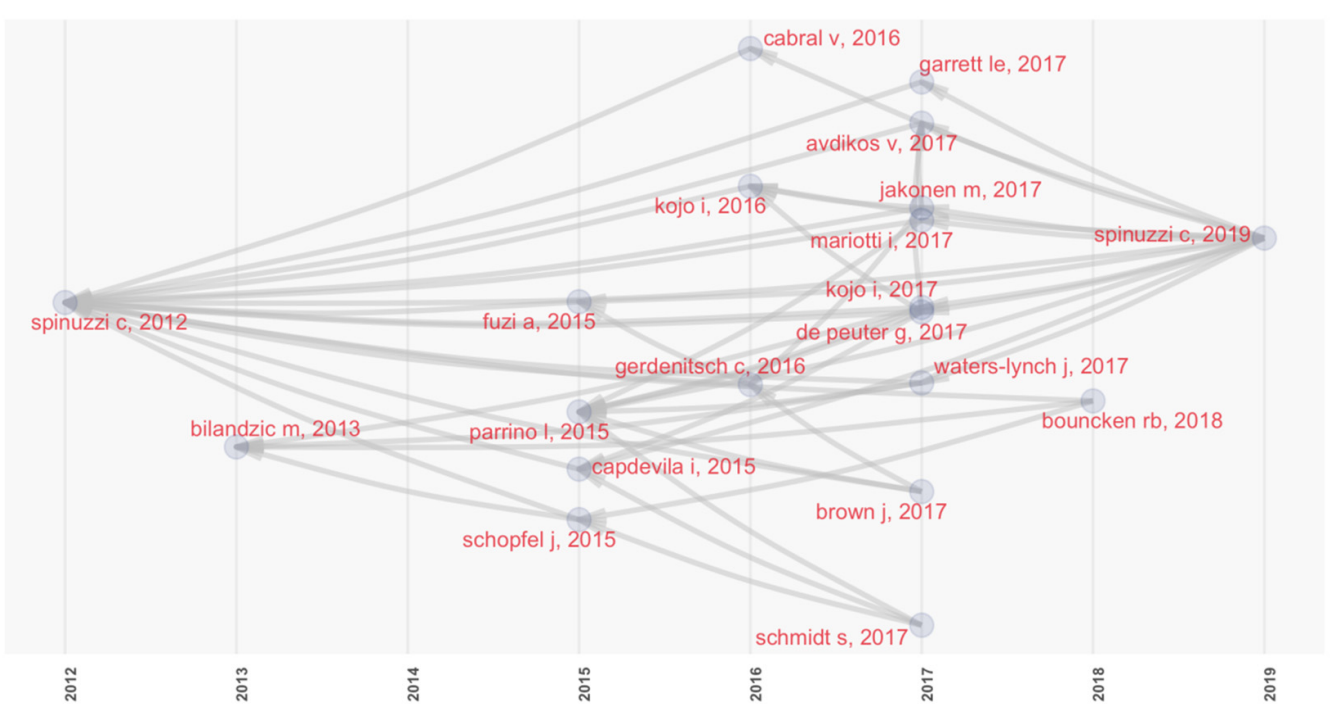

Figure 3. Historical direct citation network. This figure includes the top 20 most cited papers in scientific literature on CWSs. Arrows are plotted in a timescale based on the relationship of citations across papers.

Another feature that deserves attention in bibliometric analyses is to look at the most prolific authors (Table 4) and countries (Figure 4). The author that accumulates the highest number of publications in the field of CWSs is M. Orel, from University of Economics Prague (Czech Republic) with eight articles. Next in the list appears R.B. Bouncken with six articles from University of Bayreuth, followed by R. Appel-Meulenbroek, F-X. De Vaujany and $\mathrm{M}$. Weijs-Perree, all with three documents. Combining these numbers with those in Table 3 it can be concluded that many of the authors that have received the greatest number of citations are also remarkably productive, revealing that they have become experts in the study of CWSs.

Table 4. Most prolific authors (with at least two documents in the dataset).

\begin{tabular}{cccc}
\hline Author & Affiliation & Country & Number of Articles \\
\hline Orel, M & University of Economics Prague & Czech Republic & 8 \\
Bouncken, RB & University Bayreuth & Germany & 6 \\
Appel-Meulenbroek, R & Eindhoven University of Technology & The Netherlands & 4 \\
De Vaujany, F-X & Université Paris Dauphine-PSL & France & 4 \\
Weijs-Perree, M & Eindhoven University of Technology & The Netherlands & 4 \\
Di Marino, M & Norwegian University of Life Sciences & Norway & 3 \\
Ivaldi, S & Università Cattolica del Sacro Cuore & Italy & 3 \\
Lapintie, K & Aalto University & Finland & 3 \\
Nenonen, S & Aalto University & Finland & 3 \\
Scaratti, G & Catholic University of Milan & Italy & 3 \\
\hline
\end{tabular}

At the country level (based on the location of the institution where an author is affiliated to), Germany concentrates the highest proportion of documents (28), followed by Italy (26), UK (23) and USA (20). Next, France (15), Australia (13), Finland (11), the Czech Republic (10) and The Netherlands (10) complete the first positions. These countries do not rank high by accident. The rationale is twofold. First, Europe has more CWSs than any other continent; thus, even the US leads the world's scientific production, the European culture seems to fit well with the working approach that CWSs promote. Of course, at the country level, US hosts the highest number of CWSs, however, European countries are also the perfect place for studying this phenomenon. Second, countries such as Germany, Italy, the UK and France, with vibrant and appealing metropolis for the development of the creative class (e.g., Berlin, Milan, London, Paris) have attracted the attention of a number of co-work operators who have established their spaces. These operators share the market 
with local providers, creating thrilling co-working communities here and around the city. The above arguments seem to suggest a connection between the countries with the highest number of CWSs and the countries with the greatest productivity in the field, revealing that local researchers-who live and work there-have the perfect knowledge to investigate them.

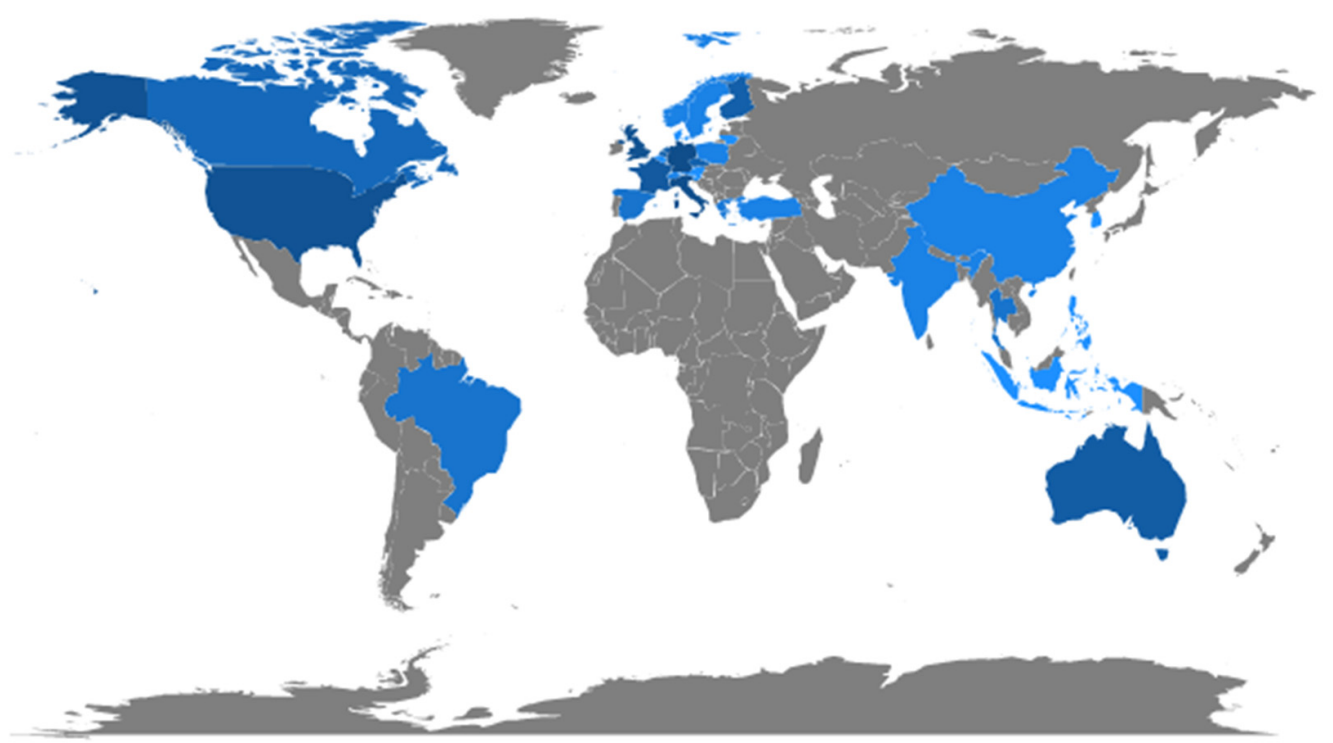

Figure 4. Scientific production by country. Note: The darkest the blue, the higher the number of documents. Countries from which there are no documents in our dataset are colored in grey.

It is also interesting to investigate the social structure of the research in co-working. More precisely, at this point it is pertinent to scrutinize whether authors tend to publish with peers from their own country or instead, prefer to collaborate with researchers from other countries. Figure 5 shows - for the ten most productive countries in the dataset-the number of documents in which there is at least one co-author from a different country (in red) and the number of documents with national co-authorship (in blue). Australia followed by the UK have the highest international collaboration intensity rates ( 0.2 and 0.18 , respectively), yet, the values are relatively low.

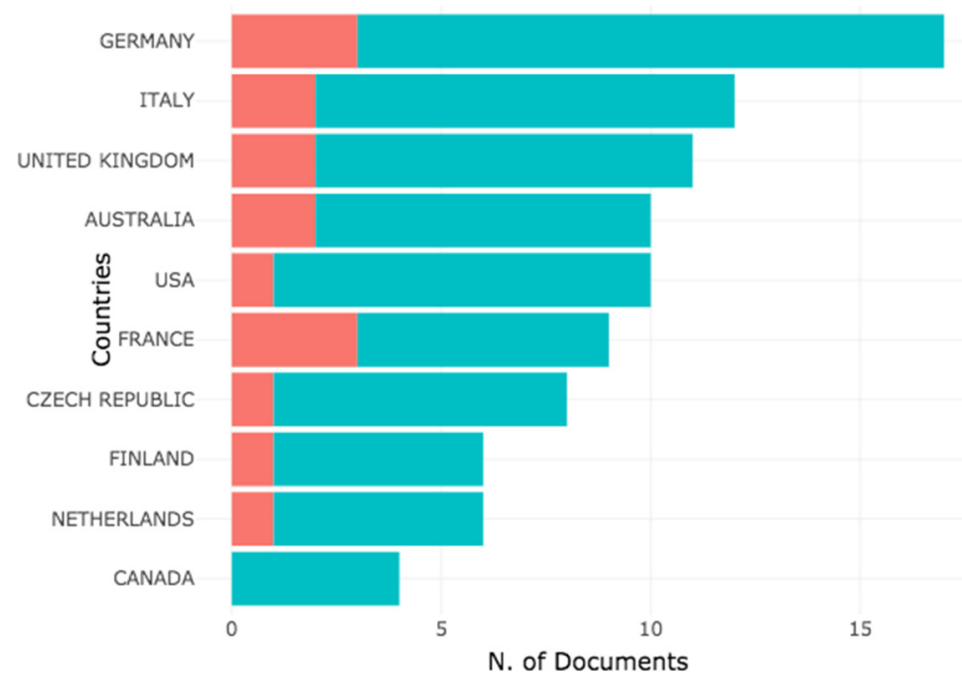

Figure 5. Corresponding author's country. Single country publications are represented by blue bars while red bars refer to multiple country publications. 
Lastly, in order to identify the sources recording the greatest impact on the study of CWSs - those responsible for publishing the highest number of articles-the R package applies the Bradford's Law [38]. As shown before in Table 1, the documents reviewed have been published in 84 different sources: 78 have appeared in academic journals, being only a small proportion (6) found in books as book chapters or proceedings. As it can be seen below in Figure 6, a small number of journals are responsible for the great majority of publications. Specifically, 13 journals have published the core of the scientific literature in the field (40 out of the 118 documents in the dataset). These articles have collectively received 556 citations, almost half $(47.24 \%)$ of the total citations received by the collection of articles analyzed.

Confronting the above results with the graphical evolution of the journals that have experienced a highest growth in terms of articles published (see Figure 7) it can be concluded that European Spatial Research and Policy is the journal that did not make its entry in the field until recently. Certainly, it is not until 2020 when this journal started paying attention to CWSs, with a total of five papers published this year. Geoforum experienced a similar pattern, with one article published in 2017 and the three remaining ones in 2020, just the opposite trend observed in the Journal of Urban Technology (three papers in 2017 and one in 2020). These three journals fall in the domain of economic geography. Consequently, in the articles published here the authors look at location patterns and the effect in the urban sphere (e.g., $[14,39,40])$. Somewhat in the middle are Sustainability-publishing papers that look at the business model of CWSs, are in search for sustainable practices for small and your firms, or focus their attention on the user's perspectives (co-workers) and the drivers for moving to a co-working space (e.g., [41,42]) —and the Journal of Corporate Real Estate-with a preference for papers that examine the characteristics of the workspace, especially the physical and operational characteristics and how they serve the ultimate purpose of CWSs (e.g., [43]).

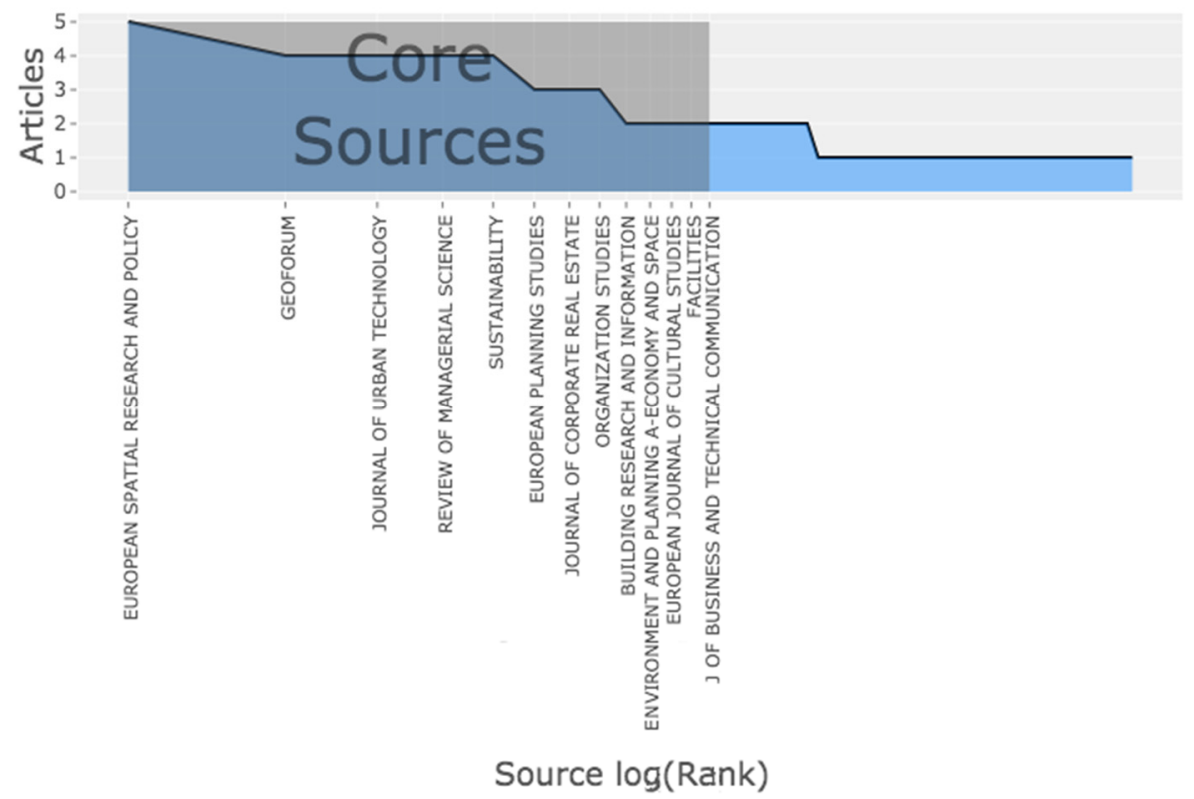

Figure 6. Core of journals publishing on the theme of CWSs. 


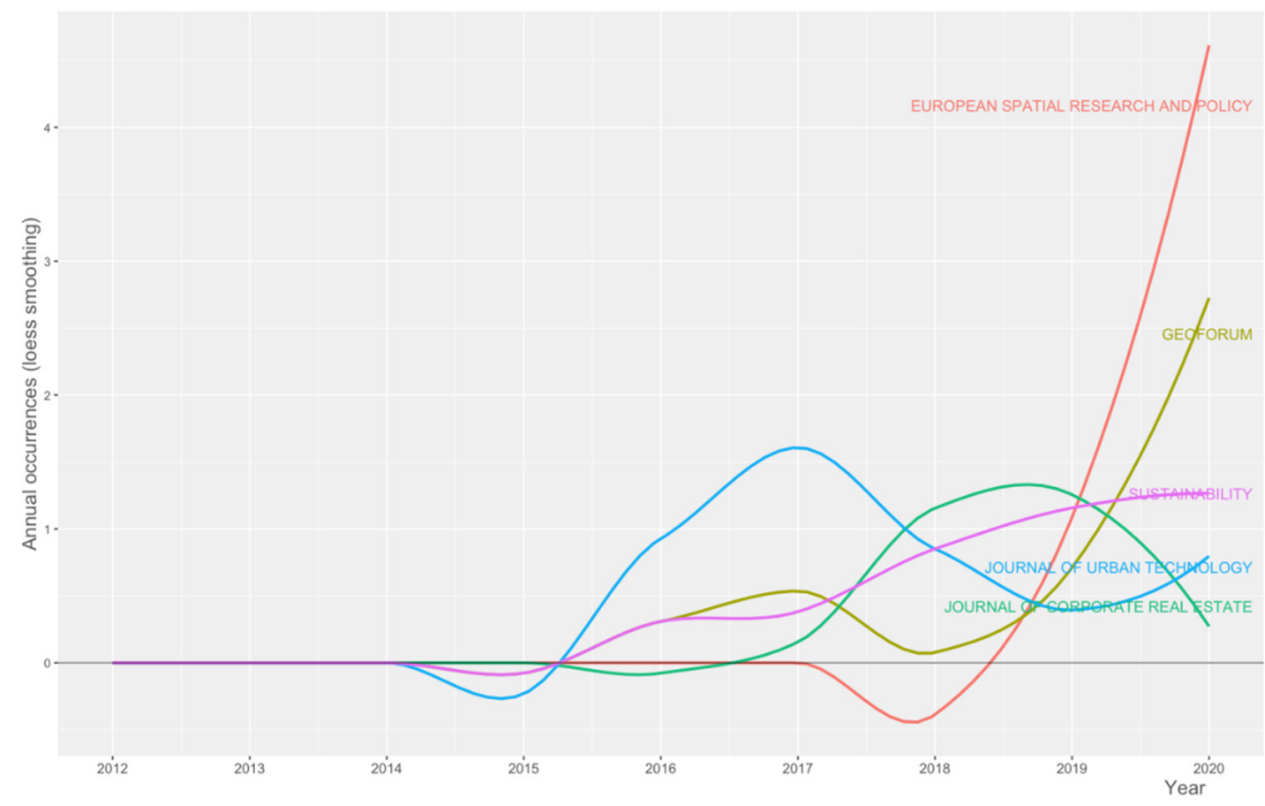

Figure 7. Source growth by year (top five journals). This graph shows the result of the Loess regression, which highlights the discontinuity in the period of the publications. To compute it the program takes into account the quantity and the publication time of the journals under analysis. The function assumes an unlimited distribution, meaning that when values are close to zero the function might display values below zero.

\section{Topics and Trends}

\subsection{Analysis of Keywords}

A first approximation to the content discussed in the documents selected can be obtained by looking at the most recurrent keywords. As previously explained, in this study KeyWords Plus is used. The results are depicted in Figure 8, showing the most common ones. The appearance of keywords such as "co-working" or "spaces" is trivial, because they are terms used to build up the query. Thus, the more informative keywords are the remaining ones. Terms such as "community" and "proximity" are found to denote the feeling of working alone yet surrounded by like-minded people, which brings not only economic benefits-due to shared spaces and infrastructures-but also psychological support and the opportunity to share one's own work experiences in a group. Unlike in a traditional workspace, co-workers have the freedom to decide how much to cooperate with others and the extent to which exchange "knowledge" —one of the other most frequent keywords-and look for synergies. Other keywords that reveal the content of this collection of academic documents are "economy" (mainly used to position CWSs in the bigger picture of the knowledge-based economy or as key players in the sharing economy), "management" (studies examining the managerial side of CWSs, and the different typologies or business models), "labor" (for those studies placing the focus on users), "industry" (to denote the rising of the co-working industry) and "telework" (as CWSs allow working remotely).

Although the previous figure assists researchers in the identification of the core terms discussed in the documents included in the dataset, it provides a static view. Figure 9 overcomes this flaw and shows how the use of these terms has evolved over time. As it can be seen, recent publications are linked with keywords such as "community", "innovation" and "economy", while discussions about the "technology", the "space" and the "organization" of these spaces seems to have lost prominence. 


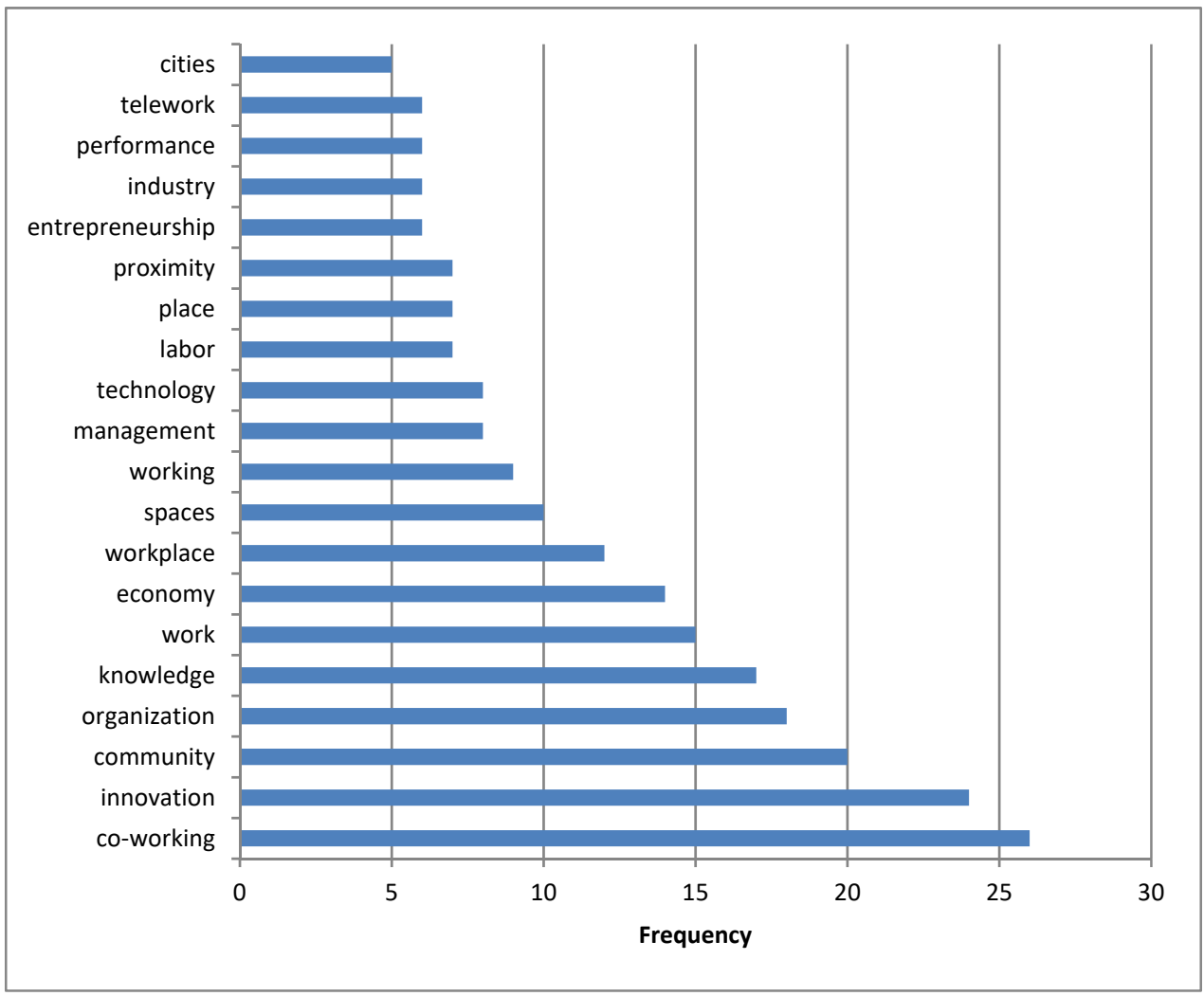

Figure 8. Most relevant keywords. The frequency is calculated as the number of documents (from those in the dataset) in which each of these terms appear listed in the KeyWords Plus.

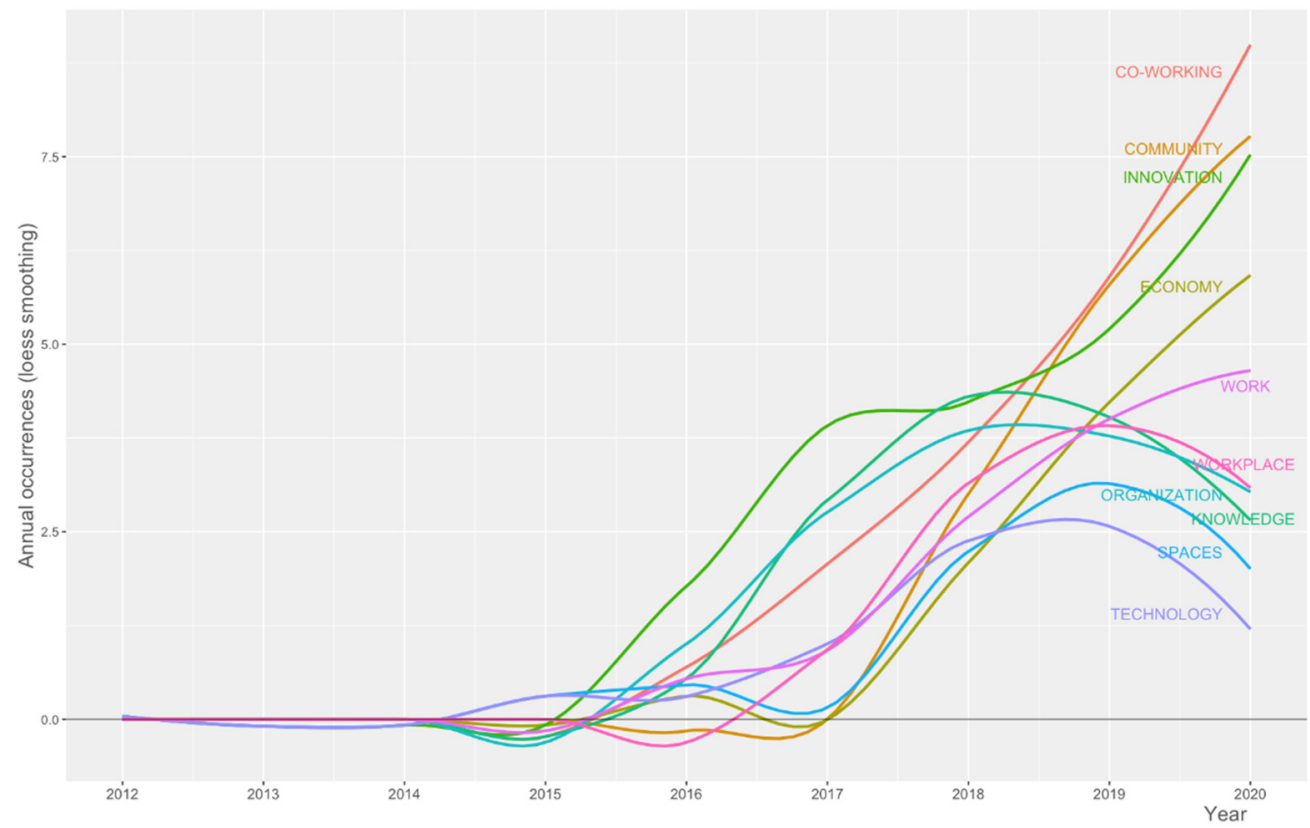

Figure 9. Word dynamics (based on KeyWords Plus). This graph shows the evolution over time of the most frequently keywords used in the documents revised. To calculate it, the program uses the Loess regression method.

\subsection{Conceptual Structure}

Figure 10 contains the word map of CWS-related research based on the MCA and k-means clustering approach, with 40 keywords distributed into four clusters (each one plotted in a different color, for illustrative purposes). The distance of a keyword from the 
origin should be interpreted as how it differs from the average profile of research on CWSs (i.e., the further away from the origin, the larger the differences). In addition, keywords that are more similar in their distribution over the publications are closer to each other.

The red cluster is the biggest one, with predominant topics including the geographical location of CWSs and their role in promoting local growth and entrepreneurial endeavors [36,44], the drivers and benefits for locating in a co-working space [45] as well as how to successfully manage them. The green cluster is somewhat more disperse, with less connections between the words, yet it reveals a group of studies devoted to learning more about the workplace, the behavior among co-workers and the relations among them (e.g., trust, behavior, creativity, alliances, etc.) [46,47]. A different pattern is that shown in the purple cluster, where keywords seem to induce to think that there is a group of studies looking at alterative spaces (e.g., libraries, coffee shops) that are adopting the principles of CWSs to fulfil the needs of their customers [33]. Finally, the blue cluster connects the term job satisfaction with the support services perceived by the co-workers, the design of the spaces, the information shared and the impact in the users' jobs [48].

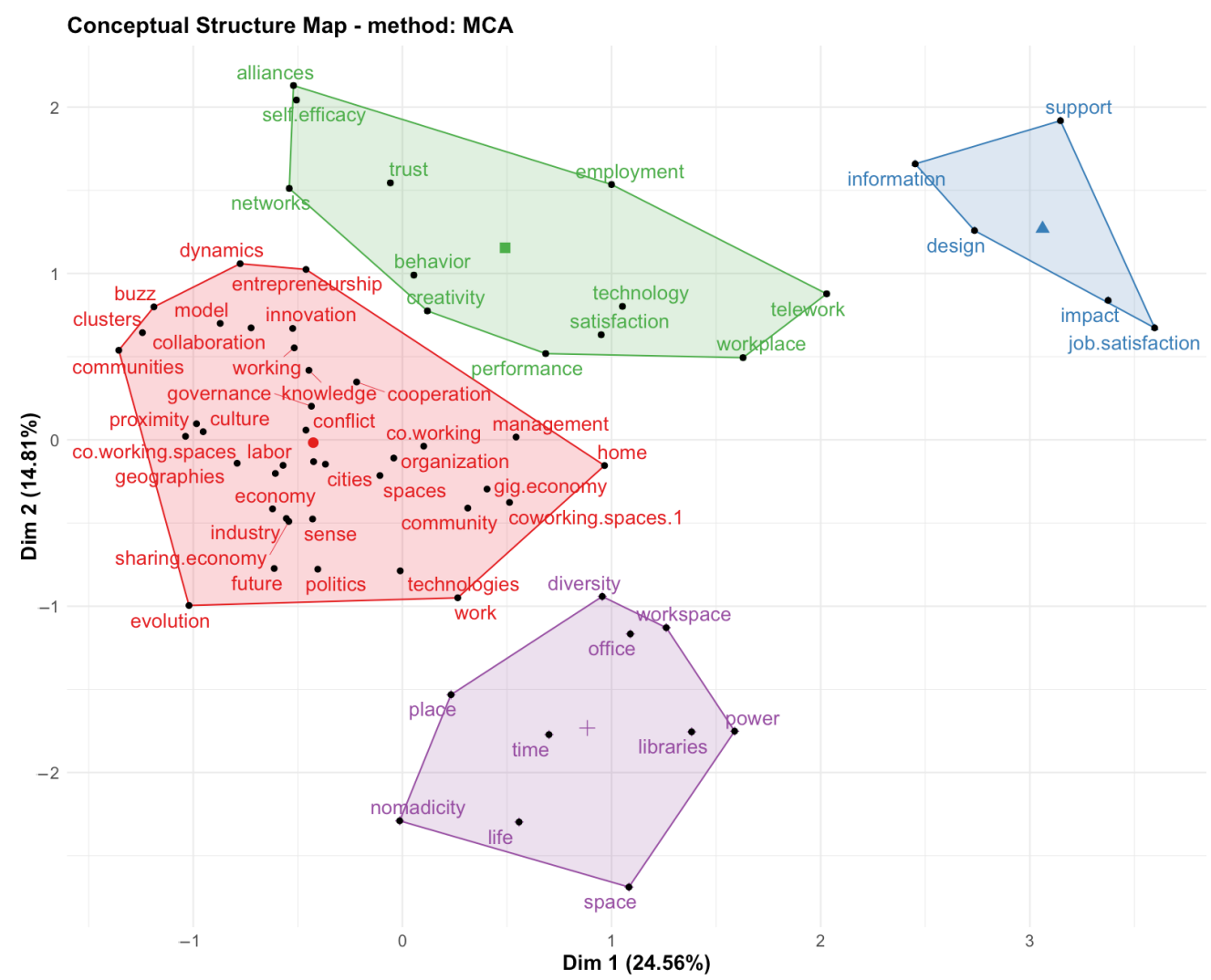

Figure 10. Word map (KeyWords Plus). This figure shows the conceptual structure of the field. To construct it factorial analysis techniques were used, employing MCA to group terms. The number of clusters was first automatically determined using the "bibliometrix" package and then refined based on expert evaluation. Dim 1 and Dim 2 are the average position of the articles included in each keyword. The midpoint of the map represents the center of the research in the field. More details on the method can be found in [20].

Moving forward in the analysis, Figure 11 shows the co-occurrence network. Not surprisingly, at the epicenter of the network the word "co-working" stands out, representing the center of the research field. Each color denotes a different cluster (or theme) of keywords. Clusters are computed using hierarchical clustering techniques. The size of the labels indicates the relevance of each term. Keywords such as "organization", "innovation", "place", "work" and "community" seem to be dominant in their respective clusters, being consistent with the results found in the previous subsection. 


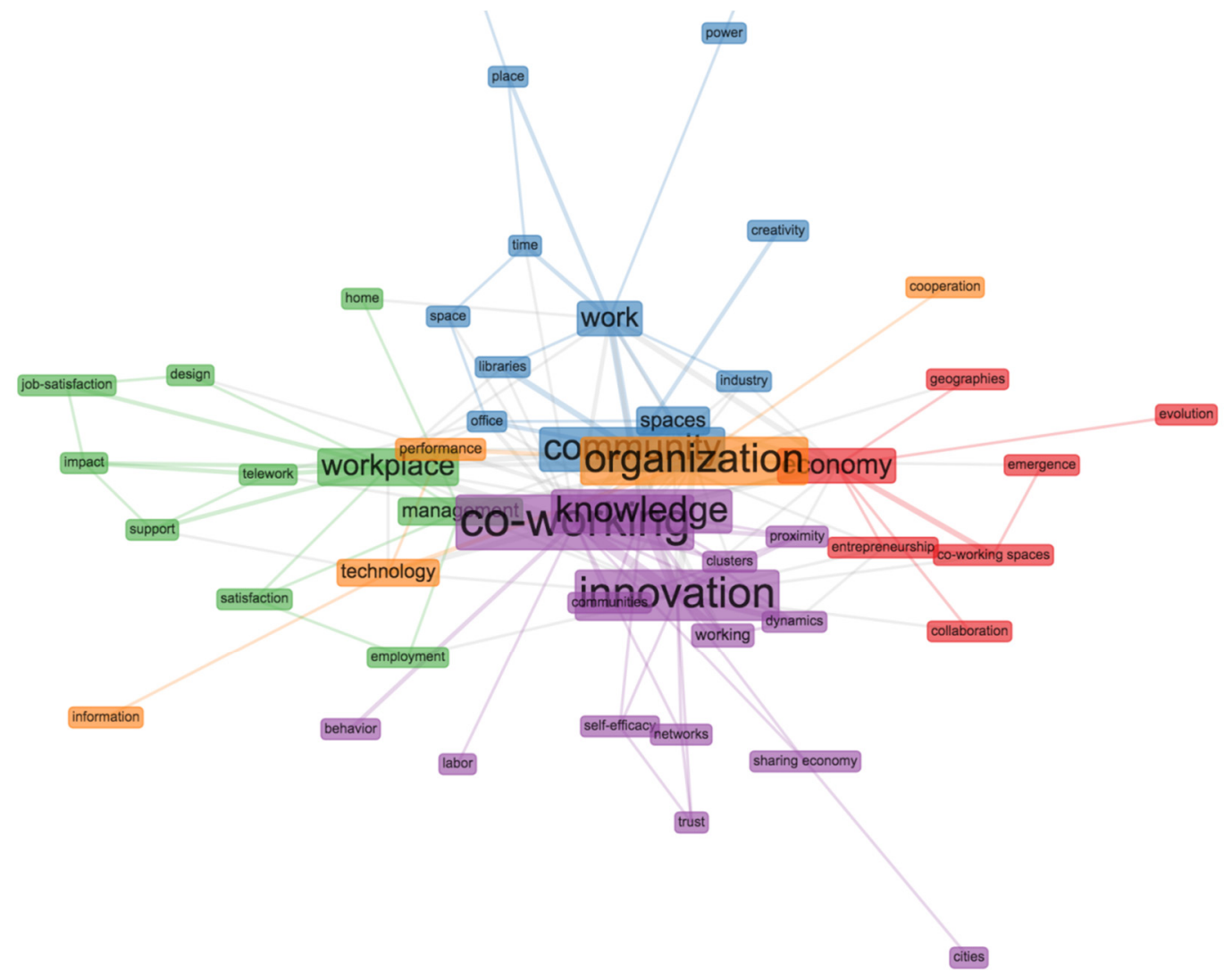

Figure 11. Co-occurrence network (KeyWords Plus). Thick lines depict a strong association between keywords, while thin ones denote weak association. Keywords without connecting lines mean that no relationship has been established between them.

As explained in the method section, the above keywords are rearranged into clusters to conform the thematic map, as shown in Figure 12. This figure plots in a very intuitive way the general strategic diagram for the literature on CWSs, and it is useful to analyze the intensity and relevance of the themes that interrelate with the topic of CWSs according to the quadrant in which they are placed. Probably, the most relevant aspect of this figure is that both the upper-left and the lower-right quadrants are the ones containing the highest number of clusters, while "motor themes" (upper-right quadrant) and "basic and transversal themes" (lower-left quadrant) are rather empty.

This distribution of clusters suggests that the literature on CWSs is somewhat atomized. One plausible explanation for this pattern is that research on CWSs is in an embryonic stage, meaning that it still needs consolidation. Equally logic is to argue that the phenomenon of CWSs has captured academics' attention from a variety of fields-e.g., management, business, architecture, psychology, etc.-who, from their disciplines, have applied their knowledge aiming at understanding and modeling the functioning of CWSs and their role in the economic, social and urban spheres. Not surprisingly, the quadrant with the highest concentration of clusters is the upper-left, containing 5 clusters that clearly signal to different areas of knowledge: entrepreneurship (blue circle), urban geography (grey circle), sustainable cities (green circle), information technologies (pink circle), and psychology of work (orange circle).

Diving deeper into each of these clusters it is possible to infer how different disciplines, with apparently different research interests, can be interconnected and the sum of them contribute to a better understanding of CWSs. Specifically, from an entrepreneurial point of view (cluster on the top-left), CWSs are seen as a tool that can foster the creation of new ventures. More specifically, studies falling in this domain investigate how CWSs have taken the classic incubator model and added it in their business model; the relevance to 
identify, assimilate, transform, and use the knowledge and synergistic opportunities that develop in a co-working environment; and how CWSs can create powerful networks with the other agents of the innovation ecosystem (e.g., [49-52]).

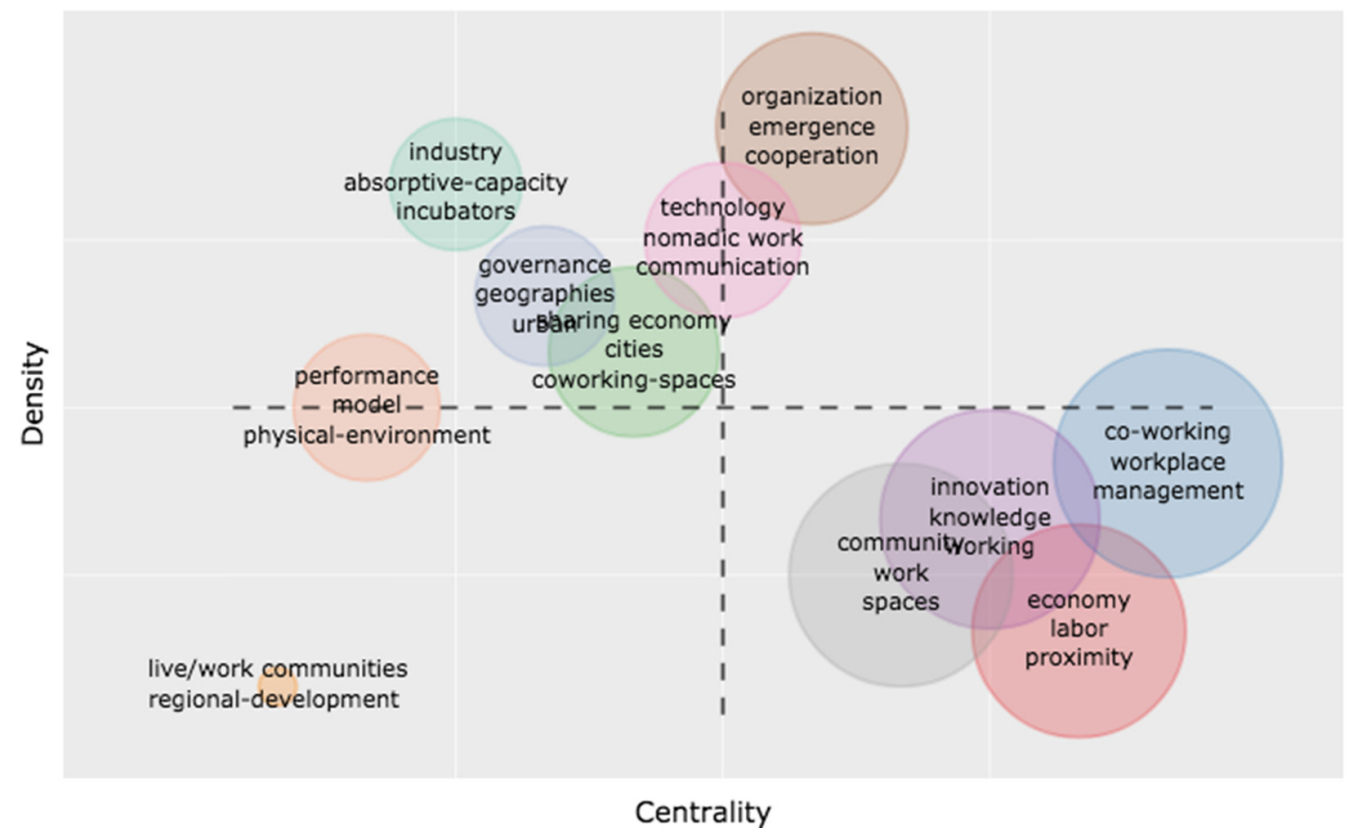

Figure 12. Thematic map showing clusters (based on KeyWords Plus) for the full period under investigation (2012-2020). The $X$-axis (centrality) accounts for the degree of interaction of a network cluster in comparison with other clusters. The $Y$-axis (density) measures the internal strength (or level of development) of a cluster network. The intersection of the two axes results into four quadrants: the upper-right quadrant contains motor themes, while the upper-left shows developed and isolated themes; the lower-right quadrant consists of emerging/declining themes, while foundational and transversal themes are shown in the lower-left quadrant. The size of the circle represents the size of the cluster which is calculated based on the number of keywords is includes.

Urban geographers and urbanists (grey circle) have also paid attention to CWSs. Studies in this area have a strong focus on regional policy and the role of CWSs in shaping urban development and regional growth (e.g., governance, geographies, public sector, urban) [53-55]. These investigations are somewhat connected with those in the green circle (sustainable cities), as there is a small overlap between these two clusters. The keywords shown in the green circle materialize in studies in which co-working initiatives are examined under the lens of the sharing or circular economy. More precisely, CWSs are conceived as a more sustainable practice to follow: resources are shared and used in a more efficient manner [56,57], and employees are empowered to work according to their own rhythms and create their own work environment [58]. Indeed, sustainable co-working has become a popular trend, as there is an increase in the number of entrepreneurs who are concerned with the global challenges and have adopted a more sustainable lifestyle [59]. Likewise, large companies are progressively incorporating sustainable practices in their corporate social responsibility strategy and business models to show their commitment with the environment and their communities [42].

The two other remaining clusters (colored in pink and orange) fall at the intersection between this quadrant (upper-left) and the two neighboring ones. On the one hand, the keywords in the pink circle are found in studies dealing with the life-style of co-workers (e.g., digital nomads) and the technical requirements they need to perform their job (e.g., need to communicate, technological requirements, social networks) $[60,61]$. On the other hand, sharing border with "basic and transversal themes", there is the orange cluster which contains keywords such as "performance", "model" and "physical environment", being 
found in papers that link productivity with the design and the culture of the office [62-64]. These articles are related with the psychology of the workplace.

Continuing the analysis, the upper-right quadrant contains the "motor themes" that are being debated in the co-working literature. These conversations are framed around the rationale behind CWSs, including discussions about the phenomenon per se (i.e., how it emerged) [2,65], the serendipity of the interactions and opportunities for cooperation $[46,66]$, as well as how CWSs should look like both in terms of the support services they might deliver to their co-workers [59,67] and from a business model perspective [43,68]. Clearly, all these keywords, to a greater or lesser extent, reflect the main essence of what CWSs are.

In the upper-low quadrant, there is only one small cluster with two keywords: "live/work communities" and "regional-development". These terms appear in the work of Buksh and Mouat [69], which presents the specific case of South-East Queensland (Australia) and looks at the interplay of agglomeration, collaborative consumption and CWSs towards urban revitalization challenges for suburban and regional development that strengthen local communities.

Finally, the lower-right quadrant brings into the table different themes that are either emerging or declining in the literature on CWSs. Additional data reveals that the themes discussed in the four clusters within this quadrant are emerging and overlapping (see Figures A1-A3 in Appendix B). Articles revolving about these keywords address issues related to co-workers' level of satisfaction [70,71], co-workers' preferences (mainly from freelancers and entrepreneurs) for belonging to a "community" instead of working in isolation [72,73] and the importance of proximity, not only to others but also to local services and facilities [14,74]. Particularly remarkable are the articles in the purple circle (with shared topics with the adjacent clusters), in which CWSs are seen as a new way of working that helps companies in keeping innovation at the forefront of their vision $[75,76]$. These terms are often discussed in the papers that fall in the intersection between this literature and that on entrepreneurship $[35,44,77]$.

\section{Directions for Future Research}

Literature on CWSs has ample room for further development. After a careful examination of the existing trends and in the middle of a global pandemic that has triggered significant changes in the way we work, live and interact with others, co-workings are expected to have a big momentum in a post-pandemic society. Within this context, four main research directions are envisioned, revolving around the following key topics: (1) the geographical location, (2) the design of the physical space, (3) the business model and (4) the creation of inclusive communities.

\subsection{Geographical Location}

CWSs are found to be spatially concentrated within the inner precincts of urban environments. The urban setting nurtures the emergence of a synergistic innovative community where the density of infrastructure and the culture of the city support the interaction among the components. The thrilling atmosphere of the inner-city neighbourhoods is a huge magnet for millennials, a generation with strong propensity for walkable areas that enable them to live close to their friends and the amenities they need. However, at a time when social distancing is one of the best tools we know to slow down the spread of the coronavirus, how will the geography of CWSs be affected? What is the impact on the urban environment? These questions are remarkable if we consider the indirect effects of CWSs on the urban context (gentrification of spaces, the development of liveable mixed-use infrastructures, the presence of restaurants, the organization of cultural venues, etc.).

Even in a pandemic situation, CWSs are sustainable pillars for the development of urban ecosystems and can act as serendipity accelerators for the development of innovative communities. Besides offering work spaces, their role is to facilitate networking opportunities with the community (e.g., universities and research centres, entrepreneurs, investors, major corporations and government). This role is of extremely importance at a time when 
the economy is still suffering the economic ill-effects of not just of the pandemic by itself but also of its collateral effects (e.g., protracted lockdown and market uncertainty).

In certain industries, teams are going to be much more flexible with the option to choose from where to work. Flexibility includes the coexistence of the two models: the traditional office headquarters with a single location and a flexible work space. Many people long for a good co-working space, so they can easily separate work from private life; however, only a few have comfortable home offices to work from. How can CWSs best fit in? Commuting to the office every day can be very time consuming, and considering the global pandemic, the use of public transport is discouraged. CWSs can be seen as a solution, providing employees with the appropriate desk spaces and meeting rooms closest to their homes. The location of the CWSs of the future might respond to new geographical demands.

\subsection{Physical Space}

Although many co-working operators are still seeing a dip in business due to COVID19 , the initial response has been quick and effective. First reactions have included ensuring members' safety by restricting access to common areas, re-coupling rooms to avoid overcrowded spaces, rearranging furniture and desks to keep workers distant from one another, ending communal breakfasts, lunches and other gatherings, and intensifying cleaning and disinfection. At this point it is worth assessing the effectiveness of these measuresbehavioral and physical workspace alterations-and their impact on the daily management of CWSs.

At a time when it is difficult to make forecasts and make decisions in the mid-term companies seek for flexibility. In this regard, CWSs will be one of the first preferences. De-densifying offices is a new request. Office spaces in cities are however expensive and many businesses are struggling financially. From a corporate point of view, CWSs stand out as a solution. On the one hand, they provide the appropriate work environment for those employees that cannot work from home. On the other hand, they are cost-effective and flexible in terms of rental agreements. Within this context, it becomes imperative to investigate how CWSs can nourish companies that are looking for space for their employees. For instance, entrepreneurs, freelancers, business owners, and workers are in need of social networks and local connections more than ever to regain their footing. Their voice needs to be listened in order to provide them with effective community hubs, which are a key ingredient in rebounding from the crisis. Likewise, the pandemic is prompting large companies to embrace telework. CWSs appear as a solution to relocate some of their employees.

\subsection{Business Models}

The COVID pandemic erupted suddenly, catching many people off guard. While at the beginning its effects were estimated to be lasting only for a short while, they now seem to have come to stay for a long period. Despite the responses discussed above (i.e., rethinking the location and the interior layout) are "a must", they are not enough to guarantee survival in the mid-term. Flexible models are needed as the workspaces as we know them now are more likely to disappear. This point raises important questions about how CWSs can resurge from the ashes and come up with innovative ways to readjust their business models and better fit new demands and users' requests. Thus, in the light of the current global pandemic, where people are encouraged to stay at home and work remotely, the business model of CWSs is no longer valid, as their main raison d'être and value-add - physical and social interactions with other co-workers-has been drastically restricted. However, far from lowering the blinds and close their doors, some CWSs have adopted new ways to keep supporting the needs of their communities. By reassessing the services and creating new solutions, the co-working industry has showcased the ability to readapt, remaining positive about the potential opportunities that may arise from this situation. 
A new working paradigm has emerged, not only questioning from "where" we work but also "when", "how" and "in which way". Not surprisingly, the service demand for CWSs has changed, being necessary to redefine the value proposition, placing more emphasis on customisation and proximity. Early versions of CWSs were geared towards specific sectors with the absence of a traditional employee or office model. The COVID-19 has completely changed this paradigm and CWSs are now seen as an attractive alternative for consultants, lawyers, and other professional services employees. Consequently, future studies might consider scrutinizing how CWSs have readjusted their business models and/or introduced new practices in response to COVID-19 and their effectiveness.

\subsection{Inclusive Communities}

CWSs and diversity have come hand in hand. Right now, there are many conversations focusing on how CWSs have been able to create a culture of inclusivity, housing people with a diversity of minds, backgrounds and profiles under a single umbrella. This diversity should be celebrated as it opens up a myriad of opportunities for exchanging experiences, perspectives and knowledge, which might help co-workers take an idea to the extra mile.

CWSs are the ideal platform (both physical and psychological) for interacting with other like-minded workers, regardless their origin, ethnicity, abilities, beliefs or gender. Although studies pointing to this direction are still scarce [78,79], there is no doubt that CWSs are in a unique position for becoming flagship initiatives in support of diversity. Several CWSs have started pioneering programs aimed at offering free membership to disadvantaged groups, helping more women tap into the networks and skills they need to start up their own business, or investing and supporting social-impact start-ups, among others. These and alike programs should be promoted, particularly in a post-COVID era, as the pandemic situation has left marginalized and disadvantaged groups less resilient and more vulnerable than before.

CWSs should therefore amplify their role model. To achieve that, CWSs will need to be creative in how they communicate. This implies changing the narrative: diversity is not about bringing diverse people in a space, but breaking down social and cultural barriers to shape and build local inclusive communities.

\section{Concluding Remarks}

Co-working spaces have become a global phenomenon. Although these spaces did not make their entry in the marketplace until recently, in just the span of a few years they have spread fast and are rapidly evolving. Moreover, the current pandemic situation has opened up new interrogates about their characteristics, role and functioning, putting these spaces at the spotlight, both in academic forums and at the practitioner sphere.

The original value of this research stems from the need to holistically map out what we do know about CWSs and the challenges ahead. In doing so, this article contributes to the understanding of CWSs by presenting the first bibliometric mapping analysis in the field. A total of 118 documents have been carefully scrutinized. With the aid of graphical visualization tools, an update of the current research status is presented. This analysis is expected to support community building as it enables scholars investigating in this domain to place themselves and their respective work. In addition, this study complements existing works that, adopting a more qualitative approach, provide a conceptual framework for the concept of co-working [40], its characteristics and business model [1,43].

Another key outcome of this study is the identification of the different topics (or themes) studies in CWSs have looked at and the interrelation of these streams. This can help scholars become more aware of the research subfields which, in turn, might help them to come up with the identification of research gaps for future research agendas. In this regard, the analysis reveals that there is a growing interest among scholars, and if experts do not fall short in their forecasts, in the forthcoming years we will see a considerable amount of works examining CWSs from their multiple perspectives. In addition, it has been noted that the topic of CWSs falls in the intersection of different research areas- 
entrepreneurship, regional science, psychology of work and architecture. Therefore, we expect to see multidisciplinary works [80] that integrate the principles of different areas into unique and original studies.

Finally, the study concludes with a contemporary overview of the challenges CWSs are facing as a result of the global pandemic and a discussion of the potential research lines that we can expect to see developed in the years to come. New research avenues for the study of co-workings have started emerging [81] that will surely help the different stakeholders-founders of CWSs, co-workers and policy makers-make better informed decisions about the directions in which the co-working industry should move forward. Likewise, new opportunities and market niches are envisioned [82,83]. All these trends require researchers' attention in order to provide alternative scenarios of what might unfold in the coming years and how to address them in order to have this industry remain at the fulcrum of innovation. CWSs are in a unique position to offer their support and act as catalyst of economic growth. It is believed that the discussion presented here will allow researchers to identify new research questions and ideas that are in the forefront of current debates. This is particularly beneficial for new researchers who have just started their journey in science and who seek intriguing research topics to work on and develop.

While a rigorous process has been followed in order to elaborate this study, it presents some limitations which, in turn, represent opportunities for future research. First, the database from where documents have been retrieved is the Web of Science, omitting other relevant databases (i.e., Scopus) and limiting the search to articles or reviews published in English language. Given that the gray literature is quite rich in the field of CWSs, future studies might decide to explore these alternative databases and document types. Second, this study uses metrics commonly used in bibliometric analysis, but other data analysis techniques might be explored to complement the picture of the current state of the art presented here. Third, despite having carefully selected the research query, it is possible to have missed some relevant documents. Notwithstanding, the approach has covered a wide spectrum of studies that have settled the theoretical background and basis for the study of CWSs. Finally, the study can be enriched by conducting a more in-depth analysis of the clusters and topics identified.

Funding: This article is one of the outputs resulting from the project on co-working spaces conducted under the mobility grant program for young researchers sponsored by the Societat Barcelonesa d'Amics del País (SEBAP) in 2019.

Institutional Review Board Statement: Not applicable.

Informed Consent Statement: Not applicable.

Data Availability Statement: The file containing the metadata of the collection of papers revised (as extracted from the Web of Science) is available upon request to the author.

Conflicts of Interest: The author declares no conflict of interest. 


\section{Appendix A}

Table A1. List of the 118 documents revised. The * denotes articles that are in early access, pending of being assigned a volume/issue number.

\begin{tabular}{|c|c|c|c|}
\hline Authors & Article Title & $\begin{array}{l}\text { Journal ISO } \\
\text { Abbreviation }\end{array}$ & Year \\
\hline $\begin{array}{l}\text { Appel-Meulenbroek, R; } \\
\text { Weijs-Perree, M; Orel, M; } \\
\text { Gauger, F; Pfnur, A }\end{array}$ & $\begin{array}{l}\text { User preferences for coworking spaces; a comparison between the } \\
\text { Netherlands, Germany and the Czech Republic }\end{array}$ & Rev. Manag. Sci. & 2020 * \\
\hline $\begin{array}{l}\text { Aroles, J; Mitev, N; de } \\
\text { Vaujany, FX }\end{array}$ & Mapping themes in the study of new work practices & $\begin{array}{l}\text { New Technol. Work } \\
\text { Employ. }\end{array}$ & 2019 \\
\hline Avdikos, V; Kalogeresis, A & $\begin{array}{l}\text { Socio-economic profile and working conditions of freelancers in } \\
\text { co-working spaces and work collectives: evidence from the } \\
\text { design sector in Greece }\end{array}$ & Area & 2017 \\
\hline Avdikos, V; Merkel, J & $\begin{array}{l}\text { Supporting open, shared and collaborative workspaces and hubs: } \\
\text { Recent transformations and policy implications }\end{array}$ & Urban Res. Pract. & 2020 \\
\hline $\begin{array}{l}\text { Babapour, M; Karlsson, M; } \\
\text { Osvalder, AL }\end{array}$ & Appropriation of an activity-based flexible office in daily work & $\begin{array}{l}\text { Nord. J. Working } \\
\text { Life Stud. }\end{array}$ & 2018 \\
\hline $\begin{array}{l}\text { Babb, C; Curtis, C; } \\
\text { McLeod, S }\end{array}$ & $\begin{array}{l}\text { The rise of shared work spaces: A disruption to urban planning } \\
\text { policy? }\end{array}$ & Urban Policy Res. & 2018 \\
\hline Bandinelli, C & $\begin{array}{l}\text { The production of subjectivity in neoliberal culture industries: } \\
\text { The case of coworking spaces }\end{array}$ & Int. J. Cult. Stud. & 2020 \\
\hline Bednar, P; Danko, L & $\begin{array}{l}\text { Coworking spaces as a driver of the post-fordist city: A tool for } \\
\text { building a creative ecosystem }\end{array}$ & $\begin{array}{l}\text { Eur. Spat. Res. } \\
\text { Policy }\end{array}$ & 2020 \\
\hline Benincasa, G & $\begin{array}{l}\text { From confined to co-working spaces: New rules and identities for } \\
\text { workplaces }\end{array}$ & $\begin{array}{l}\text { E-J. Int. Comp. } \\
\text { Labour Stud. }\end{array}$ & 2018 \\
\hline Bhattacharyya, SS; Nair, S & Explicating the future of work: perspectives from India & J. Manag. Dev. & 2019 \\
\hline $\begin{array}{l}\text { Bianchi, F; Casnici, N; } \\
\text { Squazzoni, F }\end{array}$ & $\begin{array}{l}\text { Solidarity as a byproduct of professional collaboration: Social } \\
\text { support and trust in a coworking space }\end{array}$ & Soc. Networks & 2018 \\
\hline Bilandzic, M; Foth, M & $\begin{array}{l}\text { Libraries as coworking spaces Understanding user motivations } \\
\text { and perceived barriers to social learning }\end{array}$ & Libr. Hi Tech & 2013 \\
\hline $\begin{array}{l}\text { Blagoev, B; Costas, J; } \\
\text { Karreman, D }\end{array}$ & $\begin{array}{l}\text { 'We are all herd animals': Community and organizationality in } \\
\text { coworking spaces }\end{array}$ & Organization & 2019 \\
\hline Bouncken, R; Aslam, MM & $\begin{array}{l}\text { Understanding knowledge exchange processes among diverse } \\
\text { users of coworking-spaces }\end{array}$ & J. Knowl. Manag. & 2019 \\
\hline $\begin{array}{l}\text { Bouncken, R; Ratzmann, } \\
\text { M; Barwinski, R;Kraus, S }\end{array}$ & $\begin{array}{l}\text { Coworking spaces: Empowerment for entrepreneurship and } \\
\text { innovation in the digital and sharing economy }\end{array}$ & J. Bus. Res. & 2020 \\
\hline Bouncken, RB & $\begin{array}{l}\text { University coworking-spaces: mechanisms, examples, and } \\
\text { suggestions for entrepreneurial universities }\end{array}$ & $\begin{array}{l}\text { Int. J. Technol. } \\
\text { Manage. }\end{array}$ & 2018 \\
\hline $\begin{array}{l}\text { Bouncken, RB; Aslam, } \\
\text { MM; Reuschl, AJ }\end{array}$ & The dark side of entrepreneurship in coworking-spaces & $\begin{array}{l}\text { "Inside the Mind of } \\
\text { the Entrepreneur", } \\
\text { Springer }\end{array}$ & 2018 \\
\hline $\begin{array}{l}\text { Bouncken, RB; Kraus, S; } \\
\text { Martinez-Perez, JF }\end{array}$ & $\begin{array}{l}\text { Entrepreneurship of an institutional field: The emergence of } \\
\text { coworking spaces for digital business models }\end{array}$ & $\begin{array}{l}\text { Int. Entrep. Manag. } \\
\text { J. }\end{array}$ & 2020 \\
\hline $\begin{array}{l}\text { Bouncken, RB; Laudien, } \\
\text { SM; Fredrich, V; Gormar, L }\end{array}$ & $\begin{array}{l}\text { Coopetition in coworking-spaces: Value creation and } \\
\text { appropriation tensions in an entrepreneurial space }\end{array}$ & Rev. Manag. Sci. & 2018 \\
\hline Bouncken, RB; Reuschl, AJ & $\begin{array}{l}\text { Coworking-spaces: How a phenomenon of the sharing economy } \\
\text { builds a novel trend for the workplace and for entrepreneurship }\end{array}$ & Rev. Manag. Sci. & 2018 \\
\hline Brown, J & $\begin{array}{l}\text { Curating the third place? Coworking and the mediation of } \\
\text { creativity }\end{array}$ & Geoforum & 2017 \\
\hline
\end{tabular}


Table A1. Cont.

\begin{tabular}{|c|c|c|c|}
\hline Authors & Article Title & $\begin{array}{l}\text { Journal ISO } \\
\text { Abbreviation }\end{array}$ & Year \\
\hline $\begin{array}{l}\text { Bueno, S; } \\
\text { Rodriguez-Baltanas, G; } \\
\text { Gallego, MD }\end{array}$ & Coworking spaces: A new way of achieving productivity & J. Facil. Manag. & 2018 \\
\hline Buksh, B; Mouat, CM & $\begin{array}{l}\text { Activating smart work hubs for urban revitalisation: Evidence } \\
\text { and implications of digital urbanism for planning and policy } \\
\text { from South-East Queensland }\end{array}$ & Aust. Plan. & 2015 \\
\hline Burkner, HJ; Lange, B & New geographies of work: Re-scaling micro-worlds & $\begin{array}{l}\text { Eur. Spat. Res. } \\
\text { Policy }\end{array}$ & 2020 \\
\hline Butcher, $\mathrm{T}$ & Learning everyday entrepreneurial practices through coworking & Manage. Learn. & 2018 \\
\hline Cabral, V; van Winden, W & $\begin{array}{l}\text { Coworking: An analysis of coworking strategies for interaction } \\
\text { and innovation }\end{array}$ & $\begin{array}{l}\text { Int. J. Knowl.-Based } \\
\text { Dev. }\end{array}$ & 2016 \\
\hline Capdevila, I & $\begin{array}{l}\text { Co-working spaces and the localised dynamics of innovation in } \\
\text { Barcelona }\end{array}$ & Int. J. Innov. Manag. & 2015 \\
\hline $\begin{array}{l}\text { Cappellaro, F; Cutaia, L; } \\
\text { Innella, C; Meloni, C; } \\
\text { Pentassuglia, R; Porretto, } \\
\text { V }\end{array}$ & $\begin{array}{l}\text { Investigating circular economy urban practices in Centocelle, } \\
\text { Rome district }\end{array}$ & $\begin{array}{l}\text { Environ. Eng. } \\
\text { Manag. J. }\end{array}$ & 2019 \\
\hline Castilho, MF; Quandt, CO & $\begin{array}{l}\text { Collaborative capability in coworking spaces: Convenience } \\
\text { sharing or community building? }\end{array}$ & $\begin{array}{l}\text { Technol. Innov. } \\
\text { Manag. Rev. }\end{array}$ & 2017 \\
\hline $\begin{array}{l}\text { Chance, E; Derrible, S; } \\
\text { Ashton, WS }\end{array}$ & $\begin{array}{l}\text { The need to adapt sustainability audits to atypical business } \\
\text { models }\end{array}$ & $\begin{array}{l}\text { Clean Technol. } \\
\text { Environ. Policy }\end{array}$ & 2018 \\
\hline Cheah, S; Ho, YP & $\begin{array}{l}\text { Coworking and sustainable business model innovation in young } \\
\text { firms }\end{array}$ & Sustainability & 2019 \\
\hline Cheah, S; Li, SY; Ho, YP & $\begin{array}{l}\text { Mutual support, role breadth self-efficacy, and sustainable job } \\
\text { performance of workers in young firms }\end{array}$ & Sustainability & 2019 \\
\hline $\begin{array}{l}\text { Clayton, P; Feldman, M; } \\
\text { Lowe, N }\end{array}$ & $\begin{array}{l}\text { Behind the scenes: Intermediary organizations that facilitate } \\
\text { science commercialization through entrepreneurship }\end{array}$ & $\begin{array}{l}\text { Acad. Manag. } \\
\text { Perspect. }\end{array}$ & 2018 \\
\hline $\begin{array}{l}\text { Cnossen, B; de Vaujany, } \\
\text { FX; Haefliger, S }\end{array}$ & The street and organization studies & Organ. Stud. & $2020^{*}$ \\
\hline $\begin{array}{l}\text { Coll-Martinez, E; } \\
\text { Mendez-Ortega, C }\end{array}$ & $\begin{array}{l}\text { Agglomeration and coagglomeration of co-working spaces and } \\
\text { creative industries in the city }\end{array}$ & Eur. Plan. Stud. & $2020^{*}$ \\
\hline $\begin{array}{l}\text { Constantinescu, TI; } \\
\text { Devisch, O }\end{array}$ & Portraits of work: mapping emerging coworking dynamics & Info. Commun. Soc. & 2018 \\
\hline Curaoglu, F; Demirbas, D & From co-working places to new education places & Des. J. & 2017 \\
\hline $\begin{array}{l}\text { de Peuter, G; Cohen, NS; } \\
\text { Saraco, F }\end{array}$ & $\begin{array}{l}\text { The ambivalence of coworking: On the politics of an emerging } \\
\text { work practice }\end{array}$ & Eur. J. Cult. Stud. & 2017 \\
\hline de Vaujany, FX; Aroles, J & $\begin{array}{l}\text { Nothing happened, something happened: Silence in a } \\
\text { makerspace }\end{array}$ & Manage. Learn. & 2019 \\
\hline $\begin{array}{l}\text { de Vaujany, FX; Dandoy, } \\
\text { A; Grandazzi, A; Faure, S }\end{array}$ & $\begin{array}{l}\text { Experiencing a new place as an atmosphere: A focus on tours of } \\
\text { collaborative spaces }\end{array}$ & Scand. J. Manag. & 2019 \\
\hline Di Marino, M; Lapintie, K & $\begin{array}{l}\text { Exploring multi-local working: challenges and opportunities for } \\
\text { contemporary cities }\end{array}$ & Int. Plan. Stud. & 2020 \\
\hline Di Marino, M; Lapintie, K & Emerging workplaces in post-functionalist cities & J. Urban Technol. & 2017 \\
\hline $\begin{array}{l}\text { Di Marino, M; Lilius, J; } \\
\text { Lapintie, K }\end{array}$ & $\begin{array}{l}\text { New forms of multi-local working: identifying multi-locality in } \\
\text { planning as well as public and private organizations' strategies in } \\
\text { the Helsinki region }\end{array}$ & Eur. Plan. Stud. & 2018 \\
\hline
\end{tabular}


Table A1. Cont.

\begin{tabular}{|c|c|c|c|}
\hline Authors & Article Title & $\begin{array}{l}\text { Journal ISO } \\
\text { Abbreviation }\end{array}$ & Year \\
\hline Errichiello, L; Pianese, T & Toward a theory on workplaces for smart workers & Facilities & 2019 \\
\hline Fabbri, J & $\begin{array}{l}\text { Unplugged-Place as spatio-temporal events: Empirical evidence } \\
\text { from everyday life in a coworking space }\end{array}$ & Management & 2016 \\
\hline Fiorentino, $\mathrm{S}$ & $\begin{array}{l}\text { Different typologies of 'co-working spaces' and the contemporary } \\
\text { dynamics of local economic development in Rome }\end{array}$ & Eur. Plan. Stud. & 2019 \\
\hline Fuzi, A & $\begin{array}{l}\text { Co-working spaces for promoting entrepreneurship in sparse } \\
\text { regions: the case of South Wales }\end{array}$ & Reg. Stud. Reg. Sci. & 2015 \\
\hline Gandini, A; Cossu, A & $\begin{array}{l}\text { The third wave of coworking: 'Neo-corporate' model versus } \\
\text { 'resilient' practice }\end{array}$ & Eur. J. Cult. Stud. & 2019 * \\
\hline $\begin{array}{l}\text { Garrett, LE; Spreitzer, GM; } \\
\text { Bacevice, PA }\end{array}$ & $\begin{array}{l}\text { Co-constructing a sense of community at work: The emergence of } \\
\text { community in coworking spaces }\end{array}$ & Organ. Stud. & 2017 \\
\hline $\begin{array}{l}\text { Gerdenitsch, C; Scheel, TE; } \\
\text { Andorfer, J; Korunka, C }\end{array}$ & $\begin{array}{l}\text { Coworking spaces: A source of social support for independent } \\
\text { professionals }\end{array}$ & Front. Psychol. & 2016 \\
\hline Gillen, N; Cheshire, D & $\begin{array}{l}\text { Innovation in fit-outs-are Generation } \mathrm{Y} \text { and technology firms } \\
\text { heralding a new trend? }\end{array}$ & $\begin{array}{l}\text { J. Prop. Invest. } \\
\text { Finance }\end{array}$ & 2015 \\
\hline Godfrey, A & Bundling and splitting: workspace tenure in two vectors & $\begin{array}{l}\text { Pac. Rim Prop. Res. } \\
\text { J. }\end{array}$ & $2020 *$ \\
\hline $\begin{array}{l}\text { Goermar, L; Barwinski, } \\
\text { RW; Bouncken, RB; } \\
\text { Laudien, SM }\end{array}$ & $\begin{array}{l}\text { Co-creation in coworking-spaces: Boundary conditions of } \\
\text { diversity }\end{array}$ & $\begin{array}{l}\text { Knowl. Manag. Res. } \\
\text { Pract. }\end{array}$ & 2020 * \\
\hline Grazian, D & $\begin{array}{l}\text { Thank God it's Monday: Manhattan coworking spaces in the new } \\
\text { economy }\end{array}$ & Theory Soc. & 2020 \\
\hline $\begin{array}{l}\text { Hartog, L; Weijs-Perree, M; } \\
\text { Appel-Meulenbroek, R }\end{array}$ & $\begin{array}{l}\text { The influence of personality on user satisfaction: multi-tenant } \\
\text { offices }\end{array}$ & Build. Res. Informat. & 2018 \\
\hline Hicks, M; Faulk, DG & $\begin{array}{l}\text { Do entrepreneur-focused facility incentives create economic } \\
\text { impacts? Evidence from Indiana }\end{array}$ & $\begin{array}{l}\text { J. Engrep. Public } \\
\text { Policy }\end{array}$ & 2018 \\
\hline $\begin{array}{l}\text { Houghton, KR; Foth, M; } \\
\text { Hearn, G }\end{array}$ & $\begin{array}{l}\text { Working from the other office: Trialling co-working spaces for } \\
\text { public servants }\end{array}$ & Aust. J. Public Adm. & 2018 \\
\hline Houtbeckers, E & $\begin{array}{l}\text { Researcher subjectivity in social entrepreneurship ethnographies } \\
\text { The entanglement of stories in a co-working cooperative for social } \\
\text { innovation }\end{array}$ & Soc. Enterp. J. & 2017 \\
\hline Ishitsuka, AM & $\begin{array}{l}\text { Visual encounters in global Shanghai: on the desirability of } \\
\text { bodies in a coworking space }\end{array}$ & China Perspect. & 2020 \\
\hline $\begin{array}{l}\text { Ivaldi, S; Galuppo, L; } \\
\text { Calvanese, E; Scaratti, G }\end{array}$ & $\begin{array}{l}\text { Coworking space as a practised place between welfare working } \\
\text { and managerial challenges }\end{array}$ & J. Workplace Learn. & $2020^{*}$ \\
\hline Ivaldi, S; Scaratti, G & $\begin{array}{l}\text { Coworking hybrid activities between plural objects and sharing } \\
\text { thickness }\end{array}$ & $\begin{array}{l}\text { TPM-Test. Psychom. } \\
\text { Methodol. Appl. } \\
\text { Psychol. }\end{array}$ & 2019 \\
\hline $\begin{array}{l}\text { Jakonen, M; Kivinen, N; } \\
\text { Salovaara, P; Hirkman, P }\end{array}$ & $\begin{array}{l}\text { Towards an economy of encounters? A critical study of affectual } \\
\text { assemblages in coworking }\end{array}$ & Scand. J. Manag. & 2017 \\
\hline Jamal, AC & $\begin{array}{l}\text { Coworking spaces in mid-sized cities: A partner in downtown } \\
\text { economic development }\end{array}$ & Environ. Plan. A & 2018 \\
\hline Katsikakis, D & Flexible architecture for evolving work practices & Archit. Des. & 2017 \\
\hline $\begin{array}{l}\text { Klooker, M; Nicolai, C; } \\
\text { Matzdorf, S; Trost, A; von } \\
\text { Schmieden, K; Bottcher, L; } \\
\text { Weinberg, U }\end{array}$ & $\begin{array}{l}\text { On creating workspaces for a team of teams: Learnings from a } \\
\text { case study }\end{array}$ & $\begin{array}{l}\text { "Design thinking } \\
\text { research", Springer }\end{array}$ & 2016 \\
\hline
\end{tabular}


Table A1. Cont.

\begin{tabular}{|c|c|c|c|}
\hline Authors & Article Title & $\begin{array}{l}\text { Journal ISO } \\
\text { Abbreviation }\end{array}$ & Year \\
\hline Kojo, I; Nenonen, S & Evolution of co-working places: drivers and possibilities & Intell. Buold. Int. & 2017 \\
\hline Kojo, I; Nenonen, S & Typologies for co-working spaces in Finland-what and how? & Facilities & 2016 \\
\hline Kopplin, CS & $\begin{array}{l}\text { Two heads are better than one: matchmaking tools in coworking } \\
\text { spaces }\end{array}$ & Rev. Manag. Sci. & 2020 * \\
\hline $\begin{array}{l}\text { Lapsomboonkamol, S; } \\
\text { Wiriyapinit, M; } \\
\text { Bhattarakosol, P; } \\
\text { Rajchamaha, K }\end{array}$ & $\begin{array}{l}\text { Motivational factors for knowledge sharing in co-working spaces: } \\
\text { Co-working spaces in Thailand from the management perspective }\end{array}$ & $\begin{array}{l}\text { Pertanika J. Soc. Sci. } \\
\text { Humanit. }\end{array}$ & 2020 \\
\hline Larson, EW & $\begin{array}{l}\text { Where is an organization? How workspaces are appropriated to } \\
\text { become (partial and temporary) organizational spaces }\end{array}$ & $\begin{array}{l}\text { Manag. Commun. } \\
\text { Q. }\end{array}$ & 2020 \\
\hline Lorne, $\mathrm{C}$ & $\begin{array}{l}\text { The limits to openness: Co-working, design and social innovation } \\
\text { in the neoliberal city }\end{array}$ & Environ. Plan. A & 2020 \\
\hline Luo, YL; Chan, RCK & Production of coworking spaces: Evidence from Shenzhen, China & Geoforum & 2020 \\
\hline Mariotti, I; Akhavan, M & Exploring proximities in coworking spaces: Evidence from Italy & $\begin{array}{l}\text { Eur. Spat. Res. } \\
\text { Policy }\end{array}$ & 2020 \\
\hline $\begin{array}{l}\text { Mariotti, I; Pacchi, C; Di } \\
\text { Vita, S }\end{array}$ & Co-working spaces in Milan: Location patterns and urban effects & J. Urban Technol. & 2017 \\
\hline Mayerhoffer, M & Growth factors of the coworking industry: the case of Prague & $\begin{array}{l}\text { J. Prop. Invest. } \\
\text { Finance }\end{array}$ & 2020 \\
\hline Merkel, J & $\begin{array}{l}\text { 'Freelance isn't free.' Co-working as a critical urban practice to } \\
\text { cope with informality in creative labour markets }\end{array}$ & Urban Stud. & 2019 \\
\hline Micek, G & $\begin{array}{l}\text { Studies of proximity in coworking spaces: The basic conceptual } \\
\text { challenges }\end{array}$ & $\begin{array}{l}\text { Eur. Spat. Res. } \\
\text { Policy }\end{array}$ & 2020 \\
\hline $\begin{array}{l}\text { Nakano, D; Shiach, M; } \\
\text { Koria, M; Vasques, R; dos } \\
\text { Santos, EG; Virani, T }\end{array}$ & Coworking spaces in urban settings: Prospective roles? & Geoforum & 2020 \\
\hline Orel, $\mathrm{M}$ & Supporting work-life balance with the use of coworking spaces & Equal. Divers. Incl. & 2020 \\
\hline Orel, $\mathrm{M}$ & $\begin{array}{l}\text { Life is better in flip flops. Digital nomads and their } \\
\text { transformational travels to Thailand }\end{array}$ & $\begin{array}{l}\text { Int. J. Cult. Tour. } \\
\text { Hosp. Res. }\end{array}$ & 2020 * \\
\hline Orel, $\mathrm{M}$ & $\begin{array}{l}\text { Coworking environments and digital nomadism: balancing work } \\
\text { and leisure whilst on the move }\end{array}$ & World Leisure J. & 2019 \\
\hline Orel, M; Almeida, MDA & The ambience of collaboration in coworking environments & J. Corp. Real Estate & 2019 \\
\hline Orel, M; Bennis, W & The perspective of a coworking space model in scholarly settings & Horizon & 2020 \\
\hline Orel, M; Kubatova, J & Coworking as a model for conscious business & J. Glob. Responsib. & 2019 \\
\hline Parlak, M; Baycan, T & The rise of creative hubs in Istanbul & $\begin{array}{l}\text { Eur. Spat. Res. } \\
\text { Policy }\end{array}$ & 2020 \\
\hline Parrino, L & $\begin{array}{l}\text { Coworking: Assessing the role of proximity in knowledge } \\
\text { exchange }\end{array}$ & $\begin{array}{l}\text { Knowl. Manag. Res. } \\
\text { Pract. }\end{array}$ & 2015 \\
\hline $\begin{array}{l}\text { Resch, B; Hoyer, P; } \\
\text { Steyaert, C }\end{array}$ & $\begin{array}{l}\text { Affective control in new collaborative work: Communal fantasies } \\
\text { of purpose, growth and belonging }\end{array}$ & Organ. Stud. & 2020 * \\
\hline Resch, B; Steyaert, C & $\begin{array}{l}\text { Peer collaboration as a relational practice: Theorizing affective } \\
\text { oscillation in radical democratic organizing }\end{array}$ & J. Bus. Ethics & 2020 \\
\hline $\begin{array}{l}\text { Rese, A; Kopplin, CS; } \\
\text { Nielebock, C }\end{array}$ & $\begin{array}{l}\text { Factors influencing members' knowledge sharing and creative } \\
\text { performance in coworking spaces }\end{array}$ & J. Knowl. Manag. & 2020 \\
\hline Richardson, L & $\begin{array}{l}\text { Sharing as a postwork style: Digital work and the co-working } \\
\text { office }\end{array}$ & $\begin{array}{l}\text { Camb. J. Regions } \\
\text { Econ. Soc. }\end{array}$ & 2017 \\
\hline
\end{tabular}


Table A1. Cont.

\begin{tabular}{|c|c|c|c|}
\hline Authors & Article Title & $\begin{array}{l}\text { Journal ISO } \\
\text { Abbreviation }\end{array}$ & Year \\
\hline $\begin{array}{l}\text { Robelski, S; Keller, H; } \\
\text { Harth, V; Mache, S }\end{array}$ & $\begin{array}{l}\text { Coworking spaces: The better home office? a psychosocial and } \\
\text { health-related perspective on an emerging work environment }\end{array}$ & $\begin{array}{l}\text { Int. J. Environ. Res. } \\
\text { Public Health }\end{array}$ & 2019 \\
\hline Rossitto, C; Lampinen, A & $\begin{array}{l}\text { Co-creating the workplace: Participatory efforts to enable } \\
\text { individual work at the hoffice }\end{array}$ & $\begin{array}{l}\text { Comput. Support. } \\
\text { Coop. Work }\end{array}$ & 2018 \\
\hline Rus, A; Orel, M & Coworking: A community of work & Teor. Praksa & 2015 \\
\hline $\begin{array}{l}\text { Sankari, I; Peltokorpi, A; } \\
\text { Nenonen, S }\end{array}$ & $\begin{array}{l}\text { A call for co-working-users' expectations regarding learning } \\
\text { spaces in higher education }\end{array}$ & J. Corp. Real Estate & 2018 \\
\hline $\begin{array}{l}\text { Scattoni, P; Lombardi, M; } \\
\text { Pini, M; Turi, R }\end{array}$ & $\begin{array}{l}\text { Innovative startup localization determinants and origin: A Rome } \\
\text { city case study }\end{array}$ & Ital. J. Plan. Pract. & 2019 \\
\hline Schmidt, S & $\begin{array}{l}\text { In the making: Open creative labs as an emerging topic in } \\
\text { economic geography? }\end{array}$ & Geogr. Compass & 2019 \\
\hline Schmidt, S; Brinks, V & $\begin{array}{l}\text { Open creative labs: Spatial settings at the intersection of } \\
\text { communities and organizations }\end{array}$ & Creat. Innov. Manag. & 2017 \\
\hline $\begin{array}{l}\text { Schopfel, J; Roche, J; } \\
\text { Hubert, G }\end{array}$ & $\begin{array}{l}\text { Co-working and innovation: New concepts for academic libraries } \\
\text { and learning centres }\end{array}$ & New Lib. World & 2015 \\
\hline $\begin{array}{l}\text { Seo, J; Lysiankova, L; Ock, } \\
\text { YS; Chun, D }\end{array}$ & $\begin{array}{l}\text { Priorities of coworking space operation based on comparison of } \\
\text { the hosts and users' perspectives }\end{array}$ & Sustainability & 2017 \\
\hline $\begin{array}{l}\text { Servaty, R; Perger, G; } \\
\text { Harth, V; Mache, S }\end{array}$ & $\begin{array}{l}\text { Working in a cocoon: (Co)working conditions of office } \\
\text { nomads-a health related qualitative study of shared working } \\
\text { environments }\end{array}$ & Work & 2018 \\
\hline Shearmur, R & $\begin{array}{l}\text { Conceptualising and measuring the location of work: Work } \\
\text { location as a probability space }\end{array}$ & Urban Stud. & $2020 *$ \\
\hline Spinuzzi, C & $\begin{array}{l}\text { Working alone together: Coworking as emergent collaborative } \\
\text { activity }\end{array}$ & $\begin{array}{l}\text { J. Bus. Tech. } \\
\text { Commun. }\end{array}$ & 2012 \\
\hline $\begin{array}{l}\text { Spinuzzi, C; Bodrozic, Z; } \\
\text { Scaratti, G; Ivaldi, S }\end{array}$ & $\begin{array}{l}\text { Coworking is about community: But what is community in } \\
\text { coworking? }\end{array}$ & $\begin{array}{l}\text { J. Bus. Tech. } \\
\text { Commun. }\end{array}$ & 2019 \\
\hline Tintiangko, J; Soriano, CR & $\begin{array}{l}\text { Coworking spaces in the Global South: Local articulations and } \\
\text { imaginaries }\end{array}$ & J. Urban Technol. & 2020 \\
\hline Tomal, M & $\begin{array}{l}\text { Moving towards a smarter housing market: The example of } \\
\text { Poland }\end{array}$ & Sustainability & 2020 \\
\hline $\begin{array}{l}\text { Tremblay, DG; Scaillerez, } \\
\text { A }\end{array}$ & Coworking spaces: new places for business initiatives? & $\begin{array}{l}\text { J. Innov. Econ. } \\
\text { Manag. }\end{array}$ & 2020 \\
\hline $\begin{array}{l}\text { Ungureanu, P; Cochis, C; } \\
\text { Bertolotti, F; Mattarelli, E; } \\
\text { Scapolan, AC }\end{array}$ & $\begin{array}{l}\text { Multiplex boundary work in innovation projects: The role of } \\
\text { collaborative spaces for cross-functional and open innovation }\end{array}$ & Eur. J. Innov. Manag. & 2020 * \\
\hline Vidaillet, B; Bousalham, Y & $\begin{array}{l}\text { Coworking spaces as places where economic diversity can be } \\
\text { articulated: Towards a theory of syntopia }\end{array}$ & Organization & 2020 \\
\hline Walden, J & Communicating role expectations in a coworking office & J. Commun. Manag. & 2019 \\
\hline Wang, B; Loo, BPY & $\begin{array}{l}\text { Hubs of internet entrepreneurs: The emergence of co-working } \\
\text { offices in Shanghai, China }\end{array}$ & J. Urban Technol. & 2017 \\
\hline Waters-Lynch, J; Duff, C & The affective commons of Coworking & Hum. Relat. & 2019 \\
\hline Waters-Lynch, J; Potts, J & $\begin{array}{l}\text { The social economy of coworking spaces: a focal point model of } \\
\text { coordination }\end{array}$ & Rev. Soc. Econ. & 2017 \\
\hline $\begin{array}{l}\text { Weijs-Perree, M; } \\
\text { Appel-Meulenbroek, R; } \\
\text { Arentze, T }\end{array}$ & $\begin{array}{l}\text { Location type choice for face-to-face interactions in business } \\
\text { centers }\end{array}$ & Environ. Behav. & 2020 \\
\hline
\end{tabular}


Table A1. Cont.

\begin{tabular}{|c|c|c|c|}
\hline Authors & Article Title & $\begin{array}{l}\text { Journal ISO } \\
\text { Abbreviation }\end{array}$ & Year \\
\hline $\begin{array}{l}\text { Weijs-Perree, M; van de } \\
\text { Koevering, J; } \\
\text { Appel-Meulenbroek, R; } \\
\text { Arentze, T }\end{array}$ & Analysing user preferences for co-working space characteristics & Build. Res. Informat. & 2019 \\
\hline $\begin{array}{l}\text { Wibowo, TO; Udasmoro, } \\
\text { W; Noviani, R }\end{array}$ & $\begin{array}{l}\text { Configuring the sustainable strategy of internet cafe in } \\
\text { Yogyakarta, Indonesia, to remain popular in nowadays }\end{array}$ & Entrep. Sustain. Iss. & 2020 \\
\hline $\begin{array}{l}\text { Wijngaarden, Y; Hitters, E; } \\
\text { Bhansing, PV }\end{array}$ & $\begin{array}{l}\text { Cultivating fertile learning grounds: Collegiality, tacit knowledge } \\
\text { and innovation in creative co-working spaces }\end{array}$ & Geoforum & 2020 \\
\hline $\begin{array}{l}\text { Yang, EH; Bisson, C; } \\
\text { Sanborn, BE }\end{array}$ & $\begin{array}{l}\text { Coworking space as a third-fourth place: changing models of a } \\
\text { hybrid space in corporate real estate }\end{array}$ & J. Corp. Real Estate & 2019 \\
\hline Yu, RR; Burke, M; Raad, N & $\begin{array}{l}\text { Exploring impact of future flexible working model evolution on } \\
\text { urban environment, economy and planning }\end{array}$ & J. Urban Manag. & 2019 \\
\hline
\end{tabular}

\section{Appendix B}

This appendix shows the thematic map of the two time slices that have been defined. Figure A1 contains information for the period 2012-2017, while Figure A2 does so for the period 2018-2020. Finally, Figure A3 shows the thematic evolution map of the main keywords.

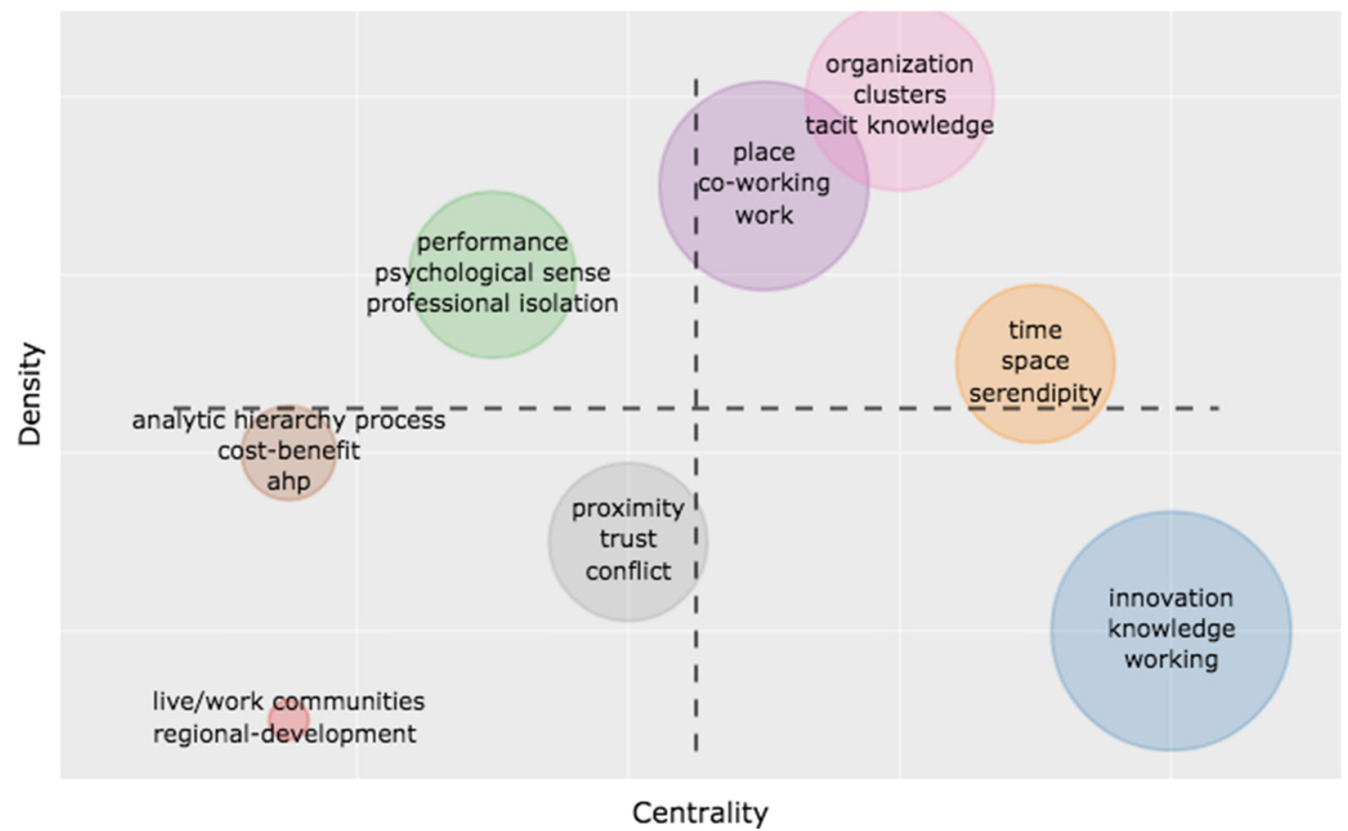

Figure A1. Thematic map. Period 2012-2017. 


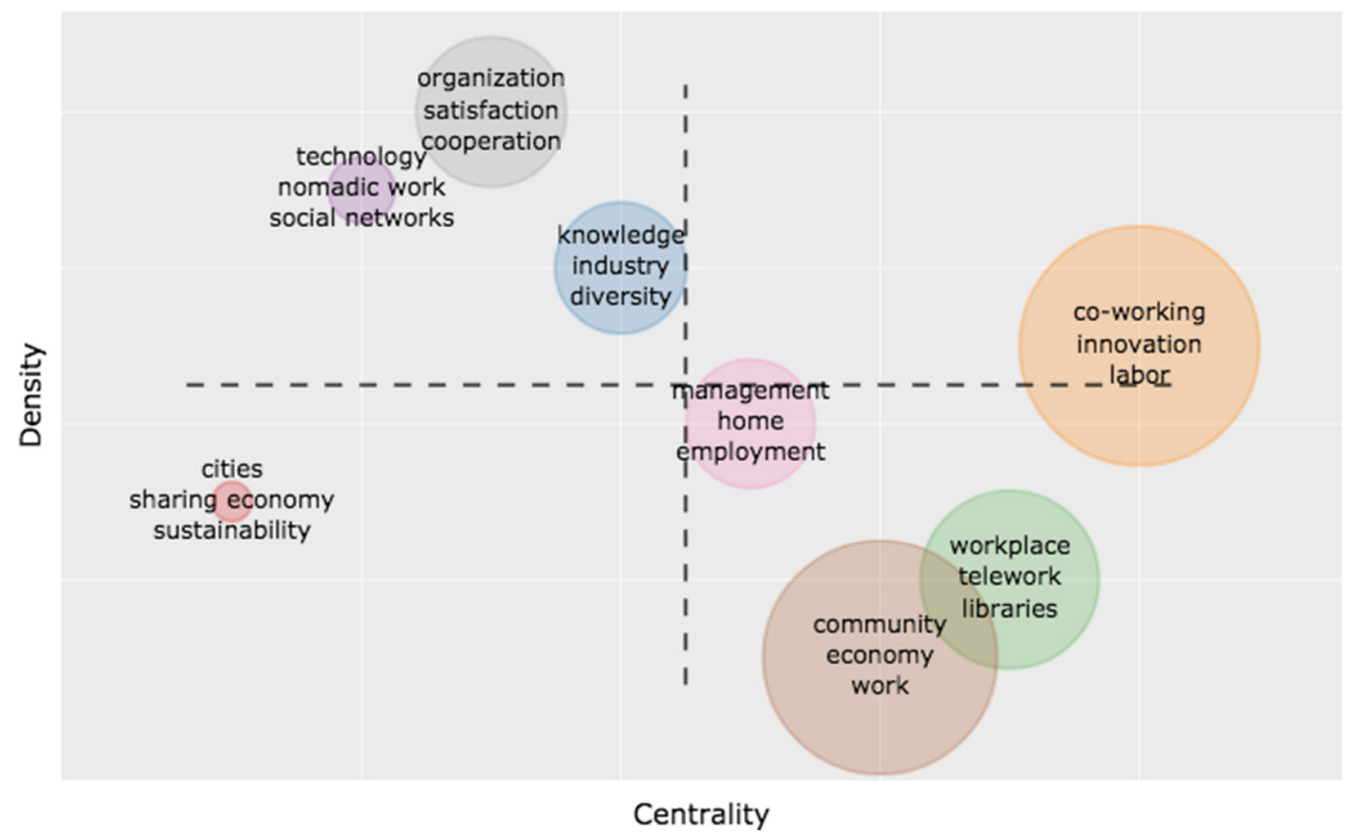

Figure A2. Thematic map. Period 2018-2020.

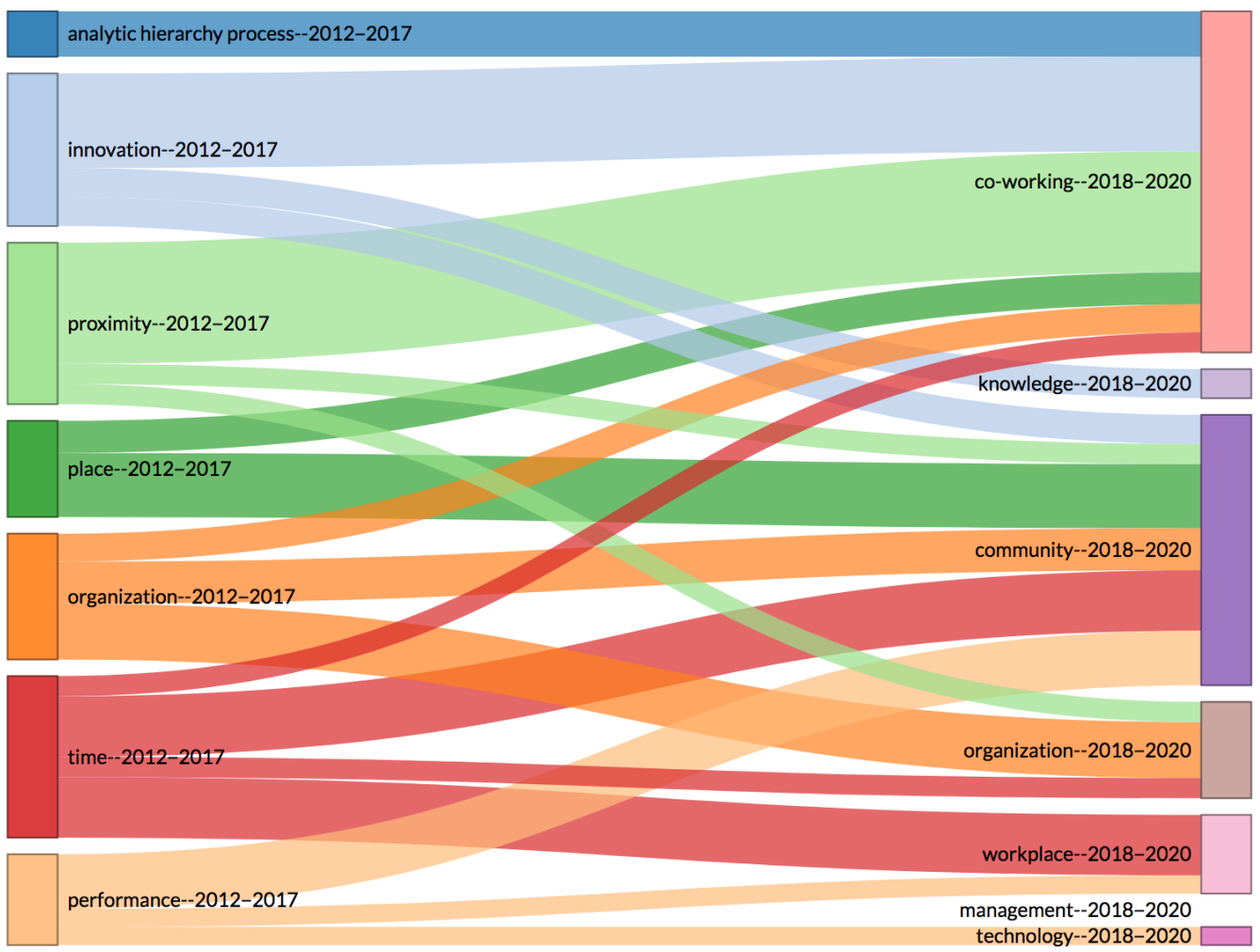

Figure A3. Thematic evolution map.

\section{References}

1. Bouncken, R.B.; Reuschl, A.J. Coworking-spaces: How a phenomenon of the sharing economy builds a novel trend for the workplace and for entrepreneurship. Rev. Manag. Sci. 2018, 12, 317-334. [CrossRef]

2. Spinuzzi, C. Working alone together: Coworking as emergent collaborative activity. J. Bus. Tech. Commun. 2012, 26, 399-441. [CrossRef]

3. Zahra, S.A.; George, G. Absorptive capacity: A review, reconceptualization, and extension. Acad. Manag. Rev. 2002, 27, 185-203. [CrossRef] 
4. Van Winden, W.; De Carvalho, L.; Van Tuijl, E.; Van Haaren, J.; Van den Berg, L. Creating Knowledge Locations in Cities. Innovation and Integration Challenge; Routledge: Abingdon, VA, USA, 2012.

5. Botsman, R.; Rogers, R. What's Mine is yours: How Collaborative Consumption is Changing the Way We Live; Collins: London, UK, 2011.

6. Feldman, M.P.; Kogler, D.F. Stylized facts in the geography of innovation. In Handbook of the Economics of Innovation; Hall, B.H., Rosenberg, N., Eds.; North-Holland: Amsterdam, The Netherlands, 2010; Volume 1, pp. 381-410.

7. Mack, E.; Mayer, H. The evolutionary dynamics of entrepreneurial ecosystems. Urban Stud. 2015, 53, 2118-2133. [CrossRef]

8. Stam, E. Entrepreneurial ecosystems and regional policy: A sympathetic critique. Eur. Plan. Stud. 2015, 23, 1759-1769. [CrossRef]

9. Appelbaum, E. The impact of new forms of work organization on workers. In Work Employment Relations in the High-Performance Workplace; Murray, G., Belanger, J., Giles, A., Lapointe, P.-A., Eds.; Routledge: London, UK, 2013; pp. 120-146.

10. Brown, B.; Green, N.; Harper, R. Wireless World: Social and Interactional Aspects of Wireless Technology; Springer: London, UK, 2001.

11. Amin, A.; Roberts, J. Knowing in action: Beyond communities of practice. Res. Policy 2008, 37, 353-369. [CrossRef]

12. Waters-Lynch, J.; Potts, J. The social economy of coworking spaces: A focal point model of coordination. Rev. Soc. Econ. 2017, 75, 417-433. [CrossRef]

13. Engel, J.S.; Berbegal-Mirabent, J.; Piqué, J.M. The renaissance of the city as a cluster of innovation. Cogent Bus. Manag. 2018, 5, 1-20. [CrossRef]

14. Mariotti, I.; Pacchi, C.; Di Vita, S. Co-working spaces in Milan: Location patterns and urban effects. J. Urban Technol. 2017, 24, 47-66. [CrossRef]

15. Jamal, A.C. Coworking spaces in mid-sized cities: A partner in downtown economic development. Environ. Plan. A Econ. Space 2018. [CrossRef]

16. Durante, G.; Turvani, M. Coworking, the sharing economy, and the city: Which role for the coworking entrepreneur'? Urban Sci. 2018, 2, 83. [CrossRef]

17. Blagoev, B.; Costas, J.; Kärreman, D. 'We are all herd animals': Community and organizationality in coworking spaces. Organization 2019, 26, 894-916. [CrossRef]

18. Zupic, I.; Čater, T. Bibliometric methods in management and organization. Organ. Res. Methods 2015, 18, 429-472. [CrossRef]

19. Fetscherin, M.; Heinrich, D. Consumer brand relationships research: A bibliometric citation meta-analysis. J. Bus. Res. 2015, 68, 380-390. [CrossRef]

20. Aria, M.; Cuccurullo, C. bibliometrix: An R-tool for comprehensive science mapping analysis. J. Infometrics 2017, 11, 959-975. [CrossRef]

21. Van Eck, N.J.; Waltman, L. CitNetExplorer: A new software tool for analyzing and visualizing citation networks. J. Informetr. 2014, 8, 802-823. [CrossRef]

22. Cobo, M.J.; López-Herrera, A.G.; Herrera-Viedma, E.; Herrera, F. SciMAT: A new science mapping analysis software tool. J. Am. Soc. Inf. Sci. Technol. 2012, 63, 1609-1630. [CrossRef]

23. Van Eck, N.J.; Waltman, L. Software survey: VOSviewer, a computer program for bibliometric mapping. Scientometrics 2010, 84, 523-538. [CrossRef]

24. Aria, M.; Alterisio, A.; Scandurra, A.; Pinelli, C.; D'Aniello, B. The scholar's best friend: Research trends in dog cognitive and behavioral studies. Anim. Cogn. 2020, 1-13. [CrossRef]

25. Aria, M.; Misuraca, M.; Spano, M. Mapping the evolution of social research and data science on 30 years of Social Indicators Research. Soc. Indic. Res. 2020, 149, 803-831. [CrossRef]

26. Cardoso, L.; Silva, R.; Almeida, G.G.F.D.; Lima Santos, L. A Bibliometric Model to Analyze Country Research Performance: SciVal Topic Prominence Approach in Tourism, Leisure and Hospitality. Sustainability 2020, 12, 9897. [CrossRef]

27. Della Corte, V.; Del Gaudio, G.; Sepe, F.; Sciarelli, F. Sustainable tourism in the open innovation realm: A bibliometric analysis. Sustainability 2019, 11, 6114. [CrossRef]

28. Xie, H.; Zhang, Y.; Choi, Y.; Li, F.A. Scientometrics Review on Land Ecosystem Service Research. Sustainability 2020, $12,2959$. [CrossRef]

29. Zhang, J.; Yu, Q.; Zheng, F.; Long, C.; Lu, Z.; Duan, Z. Comparing keywords plus of WOS and author keywords: A case study of patient adherence research. J. Assoc. Inf. Sci. Technol. 2016, 67, 967-972. [CrossRef]

30. Tijssen, R.J.; Van Raan, A.F. Mapping changes in science and technology: Bibliometric co-occurrence analysis of the R\&D literature. Eval. Rev. 1994, 18, 98-115.

31. Callon, M.; Courtial, J.P.; Laville, F. Co-word analysis as a tool for describing the network of interactions between basic and technological research: The case of polymer chemsitry. Scientometrics 1991, 22, 155-205. [CrossRef]

32. Botsman, R.; Rogers, R. What's Mine Is Yours: The Rise of Collaborative Consumption; Harper Collins: New York, NY, USA, 2011.

33. Bilandzic, M.; Foth, M. Libraries as coworking spaces: Understanding user motivations and perceived barriers to social learning. Libr. Hi Tech. 2013, 31, 254-273. [CrossRef]

34. Schopfel, J.; Roche, J.; Hubert, G. Co-Working and Innovation: New Concepts for Academic Libraries and Learning Centres. New Libr. World 2015, 116, 67-78. [CrossRef]

35. Fuzi, A. Co-working spaces for promoting entrepreneurship in sparse regions: The case of South Wales. Reg. Stud. Reg. Sci. 2015, 2, 462-469. [CrossRef] 
36. Capdevila, I. Co-working spaces and the localised dynamics of innovation in Barcelona. Int. J. Innov. Manag. 2015, 19, 1540004. [CrossRef]

37. Parrino, L. Coworking: Assessing the role of proximity in knowledge exchange. Knowl. Manag. Res. Pract. 2015, 13, 261-271. [CrossRef]

38. Bradford, S.C. Sources of information on specific subjects. Eng. An. Illus. Wkly. 1934, 3550, 85-86.

39. Micek, G. Studies of Proximity in Coworking Spaces: The Basic Conceptual Challenges. Eur. Spat. Res. Policy 2020, 27, 9-35. [CrossRef]

40. Nakano, D.; Shiach, M.; Koria, M.; Vasques, R.; dos Santos, E.G.; Virani, T. Coworking spaces in urban settings: Prospective roles? Geoforum 2020, 115, 135-137. [CrossRef]

41. Cheah, S.; Ho, Y.P. Coworking and sustainable business model innovation in young firms. Sustainability 2019, 11, 2959. [CrossRef]

42. Cheah, S.; Ho, Y.P. Mutual Support, Role Breadth Self-Efficacy, and Sustainable Job Performance of Workers in Young Firms. Sustainability 2019, 11, 3333. [CrossRef]

43. Yang, E.; Bisson, C.; Sanborn, B.E. Coworking space as a third-fourth place: Changing models of a hybrid space in corporate real estate. J. Corp. Real Estate 2019, 21, 324-345. [CrossRef]

44. Butcher, T. Learning everyday entrepreneurial practices through coworking. Manag. Learn. 2018, 49, 327-345. [CrossRef]

45. Spinuzzi, C.; Bodrožić, Z.; Scaratti, G.; Ivaldi, S. "Coworking is about community": But what is "community" in coworking? J. Bus. Tech. Commun. 2019, 33, 112-140. [CrossRef]

46. Garrett, L.E.; Spreitzer, G.M.; Bacevice, P.A. Co-constructing a sense of community at work: The emergence of community in coworking spaces. Organ. Stud. 2017, 38, 821-842. [CrossRef]

47. Rus, A.; Orel, M. Coworking: A community of work. Teor. Praksa 2015, 52, 1017-1038.

48. Gerdenitsch, C.; Scheel, T.E.; Andorfer, J.; Korunka, C. Coworking spaces: A source of social support for independent professionals. Front. Psychol. 2016, 7, 581. [CrossRef] [PubMed]

49. Clayton, P.; Feldman, M.; Lowe, N. Behind the scenes: Intermediary organizations that facilitate science commercialization through entrepreneurship. Acad. Manag. Perspect. 2018, 32, 104-124. [CrossRef]

50. Avdikos, V.; Merkel, J. Supporting open, shared and collaborative workspaces and hubs: Recent transformations and policy implications. Urban. Res. Pract. 2020, 13, 348-357. [CrossRef]

51. Parlak, M.; Baycan, T. The rise of creative hubs in Istanbul. Eur. Spat. Res. Policy 2020, 27, 127-147. [CrossRef]

52. Bouncken, R.; Aslam, M.M. Understanding knowledge exchange processes among diverse users of coworking-spaces. J. Knowl. Manag. 2019, 23, 2067-2085. [CrossRef]

53. Brown, J. Curating the "Third Place"? Coworking and the mediation of creativity. Geoforum 2017, 82, 112-126. [CrossRef]

54. Fiorentino, S. Different typologies of 'co-working spaces' and the contemporary dynamics of local economic development in Rome. Eur. Plan. Stud. 2019, 27, 1768-1790. [CrossRef]

55. Coll-Martínez, E.; Méndez-Ortega, C. Agglomeration and coagglomeration of co-working spaces and creative industries in the city. Eur. Plan. Stud. 2020, 1-22. [CrossRef]

56. Cappellaro, F.; Cutaia, L.; Innella, C.; Meloni, C.; Pentassuglia, R.; Porretto, V. Investigating circular economy urban practices in Centocelle, Rome district. Environ. Eng. Manag. J. 2019, 18, 2145-2153.

57. Orel, M.; Kubátová, J. Coworking as a model for conscious business. J. Glob. Responsib. 2019, 10, 257-270. [CrossRef]

58. Resch, B.; Hoyer, P.; Steyaert, C. Affective control in new collaborative work: Communal fantasies of purpose, growth and belonging. Organ. Stud. 2020. [CrossRef]

59. Seo, J.; Lysiankova, L.; Ock, Y.S.; Chun, D. Priorities of coworking space operation based on comparison of the hosts and users' perspectives. Sustainability 2017, 9, 1494. [CrossRef]

60. Bhattacharyya, S.S.; Nair, S. Explicating the future of work: Perspectives from India. J. Manag. Dev. 2019, 38, 175-194. [CrossRef]

61. Orel, M. Coworking environments and digital nomadism: Balancing work and leisure whilst on the move. World Leis. J. 2019, 61, 215-227. [CrossRef]

62. Bouncken, R.B.; Laudien, S.M.; Fredrich, V.; Görmar, L. Coopetition in coworking-spaces: Value creation and appropriation tensions in an entrepreneurial space. Rev. Manag. Sci. 2018, 12, 385-410. [CrossRef]

63. Rese, A.; Kopplin, C.S.; Nielebock, C. Factors influencing members' knowledge sharing and creative performance in coworking spaces. J. Knowl. Manag. 2020, 24, 2327-2354. [CrossRef]

64. Bueno, S.; Rodríguez-Baltanás, G.; Gallego, M.D. Coworking spaces: A new way of achieving productivity. J. Facil. Manag. 2018, 16, 452-466. [CrossRef]

65. Luo, Y.; Chan, R.C. Production of coworking spaces: Evidence from Shenzhen, China. Geoforum 2020, 110, 97-105. [CrossRef]

66. Jakonen, M.; Kivinen, N.; Salovaara, P.; Hirkman, P. Towards an Economy of Encounters? A critical study of affectual assemblages in coworking. Scand. J. Manag. 2017, 33, 235-242. [CrossRef]

67. Orel, M. Supporting work-life balance with the use of coworking spaces. Equal. Divers. Incl. An. Int. J. 2019, 39, 549-565. [CrossRef]

68. Kojo, I.; Nenonen, S. Typologies for co-working spaces in Finland-what and how? Facilities 2016, 34, 302-313. [CrossRef]

69. Buksh, B.; Mouat, C.M. Activating smart work hubs for urban revitalisation: Evidence and implications of digital urbanism for planning and policy from South-East Queensland. Aust. Plan. 2015, 52, 16-26. [CrossRef] 
70. Hartog, L.; Weijs-Perrée, M.; Appel-Meulenbroek, R. The influence of personality on user satisfaction: Multi-tenant offices. Build. Res. Inf. 2018, 46, 402-416. [CrossRef]

71. Babapour, M.; Karlsson, M.; Osvalder, A.L. Appropriation of an activity-based flexible office in daily work. Nord. J. Work. Life Stud. 2018, 8. [CrossRef]

72. Appel-Meulenbroek, R.; Weijs-Perrée, M.; Orel, M.; Gauger, F.; Pfnür, A. User preferences for coworking spaces; a comparison between the Netherlands, Germany and the Czech Republic. Rev. Manag. Sci. 2020, 1-24. [CrossRef]

73. Tintiangko, J.; Soriano, C.R. Coworking Spaces in the Global South: Local Articulations and Imaginaries. J. Urban. Technol. 2020, 27, 67-85. [CrossRef]

74. Di Marino, M.; Lapintie, K. Exploring multi-local working: Challenges and opportunities for contemporary cities. Int. Plan. Stud. 2020, 25, 129-149. [CrossRef]

75. Cabral, V.; Winden, W.V. Coworking: An analysis of coworking strategies for interaction and innovation. Int. J. Knowl. Based Dev. 2016, 7, 357-377. [CrossRef]

76. Bouncken, R.; Ratzmann, M.; Barwinski, R.; Kraus, S. Coworking spaces: Empowerment for entrepreneurship and innovation in the digital and sharing economy. J. Bus. Res. 2020, 114, 102-110. [CrossRef]

77. Bouncken, R.B.; Aslam, M.M.; Reuschl, A.J. The dark side of entrepreneurship in coworking-spaces. In Inside the Mind of the Entrepreneur. Cognition, Personality Traits, Intention and Gender Behavior; Tur Porcar, A., Ribeiro Soriano, D., Eds.; Springer: Cham, Switzerland, 2018; pp. 135-147.

78. Goermar, L.; Barwinski, R.W.; Bouncken, R.B.; Laudien, S.M. Co-creation in coworking-spaces: Boundary conditions of diversity. Knowl. Manag. Res. Pract. 2020, 1-12. [CrossRef]

79. Vidaillet, B.; Bousalham, Y. Coworking spaces as places where economic diversity can be articulated: Towards a theory of syntopia. Organization 2020, 27, 60-87. [CrossRef]

80. Waters-Lynch, J.; Potts, J.; Butcher, T.; Dodson, J.; Hurley, J. Coworking: A Transdisciplinary Overview. 2016. Available online: https:/ / ssrn.com/abstract=2712217 (accessed on 25 January 2021).

81. Ashforth, B.E. Identity and identification during and after the pandemic: How might COVID-19 change the research questions we ask? J. Manag. Stud. 2020, 57, 1763-1766. [CrossRef]

82. Mariotti, I.; Di Matteo, D. Coworking in emergenza Covid-19: Quali effetti per le aree periferiche? EyesReg 2020, 10. Available online: http:/ / www.eyesreg.it/2020/ coworking-in-emergenza-covid-19-quali-effetti-per-le-aree-periferiche/ (accessed on 25 January 2021).

83. Gruenwald, H. Coworking spaces in Germany during the Covid-19 crisis utilized for homeoffice and homeschooling. South Asian J. Soc. Stud. Econ. 2020, 8, 57-67. [CrossRef] 